\title{
KEBERKESANAN LATIHAN ASAS KEPOLISAN KADET INSPEKTOR TERHADAP AMALAN INTEGRITI DALAM KALANGAN PEGAWAI KANAN POLIS
}

\section{THE EFFECTIVENESS OF INSPECTOR CADET POLICE BASIC TRAINING TOWARDS INTEGRITY PRACTICES AMONG SENIOR POLICE OFFICER}

\author{
Norashikin Ahmad $^{1 *}$, Sity Daud ${ }^{1}$ and Anis Yusal Yusoff ${ }^{2}$ \\ ${ }^{1}$ Research Centre for History, Politics and International Affairs, Faculty of Social \\ Sciences and Humanities, Universiti Kebangsaan Malaysia, Selangor, MALAYSIA \\ ${ }^{2}$ Institute of Ethnic Studies, Universiti Kebangsaan Malaysia, Selangor, \\ MALAYSIA
}

"Corresponding author: norashikin771209@gmail.com

Published online: 29 October 2021

To cite this article: Norashikin Ahmad, Sity Daud and Anis Yusal Yusoff. 2021. Keberkesanan latihan asas kepolisan kadet inspektor terhadap amalan integriti dalam kalangan pegawai kanan polis. Kajian Malaysia 39(2): 233-266. https://doi.org/10.21315/km2021.39.2.10

To link to this article: https://doi.org/10.21315/km2021.39.2.10

\begin{abstract}
This study is an assessment of the effectiveness of the Inspector Cadet Police Basic Training Programme on the practice of integrity as a result of the implementation of the Royal Malaysian Police (RMP) Integrity Plan. The training programme is aimed at creating senior police officers who practice good governance in order to improve the quality of service delivery and management as well as to create an excellent image of RMP. The RMP's commitment to upholding integrity has been proven by management improvements through the implementation of some initiatives such as the establishment of the Department of Integrity and Standard Compliance and the implementation of the RMP Integrity Plan, and the implementation of the Enforcement Agency Integrity Module in the RMP training module. This descriptive study uses a qualitative approach based on a structured design of a case study. Primary data were obtained through a semistructured interview method with eight informants selected through purposive sampling techniques and supported by secondary data through document analysis and library research. The findings show that the training module has been a
\end{abstract}


dominant influence and the main catalyst for the practice of integrity, apart from workplace environment and family as new findings. The study concludes that the implementation of the integrity learning module in the Police Basic Training Programme has provided the knowledge and skills towards the inculcation of integrity but somehow officers can still be influenced by work environment and family factors.

Keywords: integrity practice, training effectiveness, service delivery, management improvement, workplace environment

\begin{abstract}
ABSTRAK
Kajian ini merupakan satu penilaian tentang keberkesanan Program Latihan Asas Kepolisan (PLAK) Kadet Inspektor terhadap amalan integriti lanjutan pengimplimentasian Pelan Integriti Polis Diraja Malaysia (PDRM). Program latihan tersebut bertujuan melahirkan pegawai kanan polis yang mengamalkan tadbir urus baik bagi meningkatkan mutu penyampaian perkhidmatan dan pengurusan serta membentuk imej PDRM yang cemerlang. Kesungguhan PDRM memartabatkan integriti jelas menerusi penambahbaikan pengurusan melalui pelaksanaan inisiatif seperti penubuhan Jabatan Integriti dan Pematuhan Standard, pelaksanaan Pelan Integriti PDRM dan penerapan Modul Integriti Agensi Penguatkuasaan dalam modul latihan PDRM. Kajian deskriptif ini menggunakan pendekatan kualitatif yang distrukturkan dengan reka bentuk kajian kes. Data primer diperoleh menerusi kaedah temu bual separa berstruktur terhadap lapan orang informan menggunakan teknik persampelan bertujuan dan disokong data sekunder menerusi kajian dokumen dan kepustakaan. Dapatan kajian mendapati modul latihan mendominasi pengaruh dan menjadi pemangkin utama amalan integriti, di samping persekitaran tempat kerja dan keluarga sebagai penemuan baru. Kajian menyimpulkan bahawa penerapan modul integriti dalam model latihan PLAK telah meningkatkan pengetahuan dan kemahiran ke arah sikap yang berintegriti, namun pengamalannya masih dipengaruhi faktor persekitaran tempat kerja dan faktor keluarga.
\end{abstract}

Kata kunci: amalan integriti, keberkesanan latihan, penyampaian perkhidmatan, penambahbaikan pengurusan, persekitaran kerja 


\section{PENDAHULUAN}

Polis Diraja Malaysia (PDRM) menerusi Akta Polis (1967) telah diberikan kuasa, peruntukan perundangan dan peraturan yang menerapkan nilai integriti dalam organisasi. Perintah Tetap Ketua Polis Negara: A110 - Tatatertib (2017), Sistem Kawalan Dadah dan Disiplin (2017) serta Peraturan-peraturan Pegawai Awam (Kelakuan \& Tatatertib) (1993) merupakan medium kawalan disiplin warga polis. Pengimplimentasian Pelan Integriti PDRM 2016-2020 (Polis Diraja Malaysia 2016), penguatkuasaan Akta Suruhanjaya Integriti Agensi Penguatkuasaan (2009) dan penerapan Modul Integriti Agensi Penguatkuasaan (Mohammad Diah dan Harisham 2016) dalam modul Program Latihan Asas Kepolisan (PLAK) Kadet Inspektor mengukuhkan usaha pembudayaan integriti mendukung etos perkhidmatan awam (MAMPU 2012).

Perintah Tetap Ketua Polis Negara (2003, 673-717) merungkai peranan, bentuk latihan dan pengisian PLAK. PLAK berorientasikan ilmu pengetahuan, kemahiran dan sikap, mentransformasi sikap orang awam menjadi seorang pegawai kanan polis. Tempoh latihan selama sembilan bulan dijalankan di Pusat Latihan Polis (PULAPOL) Kuala Lumpur oleh jurulatih dan pensyarah terlatih. Skop latihan mencakupi asas kepolisan, kecergasan fizikal, kepimpinan, modul undang-undang, penggunaan senjata, kawad, modul keagamaan, teknologi maklumat dan tadbir urus. Penilaian secara intensif dilaksanakan sepanjang tempoh latihan. Sejak November 2016, Modul Integriti Agensi Penguatkuasaan (Mohammad Diah dan Harisham 2016), menjadi modul utama dalam PLAK dengan pengisian khusus pembentukan sahsiah melalui modul integriti, meningkatkan kefahaman dan penghayatan integriti dalam kalangan pelatih pegawai kanan polis.

Selain penerapan menerusi latihan, Jabatan Integriti dan Pematuhan Standard (JIPS) secara berterusan memantau, mengawasi dan melaksanakan penguatkuasaan di setiap formasi. Komitmen penguatkuasaan JIPS mengurangkan jumlah kes pelanggaran integriti seperti di Jadual 1, namun sebagai agensi penguatkuasa utama negara, pelanggaran integriti warga polis merosakkan imej organisasi dan boleh menggugat keselamatan negara.

Berdasarkan Jadual 1, kumpulan pegawai polis berpangkat inspektor mencatat pelanggaran integriti tertinggi berjumlah $21.3 \%$ berbanding lain-lain pangkat. Hal ini menunjukkan penerapan dan penguatkuasaan integriti masih gagal mengekang kes seumpamanya bagi kumpulan berkenaan. 
Jadual 1: Statistik pelanggaran integriti PDRM dari tahun 2015 hingga 2017 mengikut pecahan pangkat

\begin{tabular}{lrrr}
\hline Pangkat/tahun & 2015 & 2016 & 2017 \\
\hline Komisioner Polis (CP) & 2 & 2 & 1 \\
Deputi Komisioner Polis (DCP) & 2 & 3 & 2 \\
Senior Asisten Komisioner Polis (SAC) & 6 & 14 & 13 \\
Asisten Komisioner Polis (ACP) & 26 & 37 & 33 \\
Superintenden Polis (SUPT.) & 35 & 60 & 48 \\
Deputi Superintenden Polis (DSP) & 80 & 101 & 91 \\
Asistan Superintenden Polis (ASP) & 240 & 380 & 333 \\
Inspektor (INSP) & 710 & 931 & 1,014 \\
Sub-Inspektor (SI) & 35 & 59 & 30 \\
Sarjan Mejar (SM) & 73 & 120 & 123 \\
Sarjan (SJN) & 431 & 635 & 652 \\
Koperal (KPL) & 575 & 979 & 788 \\
Lans Koperal (L/KPL) & 443 & 995 & 652 \\
Konstabel (KONST) & 171 & 407 & 284 \\
Anggota sokongan (SKGN) & 240 & 366 & 237 \\
\hline
\end{tabular}

Sumber: Jabatan Integriti dan Pematuhan Standard (2019).

Justeru, adalah penting untuk mengkaji keberkesanan PLAK Kadet Inspektor bagi melahirkan kumpulan inspektor yang berintegriti tinggi. Kajian ini menganalisis amalan integriti dalam kalangan inspektor setelah mengikuti PLAK Kadet Inspektor bagi mencapai objektif kajian seperti berikut:

1. Mengenal pasti pengisian program latihan integriti dalam PLAK Kadet Inspektor.

2. Menganalisis kesan program latihan integriti.

Pertikaian integriti warga polis di peringkat antarabangsa membabitkan hujah berhubung impak latihan kepolisan terhadap pemilikan integriti warga polis. Blumberg, Giromini dan Jacobson (2015) mengkaji impak latihan terhadap integriti. Pengenalpastian pengisian program latihan integriti dalam PLAK penting bagi melihat kewujudan elemen integriti kepolisan diterapkan dalam proses pembentukan personaliti kepolisan. Pengisian program diteliti menjurus kepada penekanan aspek perubahan sikap, pengetahuan dan kemahiran berintegriti. Penelitian ini membolehkan pencapaian objektif kedua dengan mengkaji impak penerapan modul latihan integriti terhadap perubahan sikap, 
pengetahuan dan kemahiran setelah berada dalam persekitaran kerja. Hal ini dapat mengukur keberkesanan dan kekuatan program latihan yang dijalankan, selain dapat memberikan pengetahuan tentang faktor yang mempengaruhi amalan integriti.

\section{SOROTAN LITERATUR}

Menurut Pelan Integriti Nasional (2004, 17-18), integriti ialah kualiti unggul yang wujud pada individu dan organisasi berlandaskan etika yang menjadi cerminan dalam tindakan seharian. Pembudayaan nilai moral, etika dan integriti memperkukuhkan etos perkhidmatan awam di Malaysia (MAMPU 2012). Etika ialah suatu set piawaian tingkah laku individu, organisasi dan kerjaya menerapkan nilai integriti, mencakupi kualiti unggul setiap komponen tersebut. Piawaian menetapkan pemilihan perkara baik, pematuhan ketetapan piagam dan kod etika organisasi mahupun kerjaya yang membawa kepada pembudayaan nilai murni dan pematuhan amalan. Kod etika PDRM menetapkan warga polis agar prihatin dan komited melaksanakan fungsi PDRM, responsif dalam memberikan perkhidmatan terbaik kepada masyarakat, membudayakan integriti dan semangat satu pasukan, meningkatkan kualiti perkhidmatan menerusi amalan inovatif dan kreatif serta bersikap profesional ke arah merealisasikan kepolisan moden.

Megat Ayop dan Abd. Halim (2016a; 2016b; 2016c) menegaskan bahawa nilai dan norma integriti mengandungi ketetapan yang perlu dipatuhi oleh individu dan organisasi termasuk penjawat awam. Pelan Integriti Nasional $(2004,18)$ merungkai amalan integriti berdasarkan pengkelasan jenis integriti iaitu individu, organisasi dan penjawat awam. Keselarasan tindakan yang cepat, tepat dan bermutu oleh seseorang individu dalam pelbagai keadaan secara konsisten merupakan pentafsiran integriti individu. Tindakan perlu selaras dengan ungkapan kata-kata, prinsip moral, etika, peruntukan undang-undang, kepentingan diri dan kepentingan umum.

Integriti organisasi wujud dalam keseluruhan pelaksanaan kod etika, piagam pelanggan, sistem kerja dan pematuhan amalan baik organisasi. Ketegasan organisasi mengulangi kod etika untuk penghayatan warganya menjayakan pembudayaan integriti organisasi. Penjawat awam berintegriti mengutamakan kepentingan umum dalam melaksanakan amanah dan menggunakan kuasa secara telus dan tulus. Pembudayaan nilai integriti, kerjasama dan kesepakatan, mengutamakan kepentingan umum, kesegeraan, berinovasi, membudayakan ilmu, bermusyawarah dan keterbukaan menerima kritikan melahirkan 
etos perkhidmatan awam yang mentransformasi sektor awam negara bagi menghadapi cabaran perkhidmatan yang semakin kompleks (MAMPU 2012).

Pewartaan peraturan kelakuan dan tatatertib penjawat awam membangunkan modal insan minda kelas pertama dan memelihara imej perkhidmatan awam di Malaysia (Akauntan Negara Malaysia 2019, 5). Kedudukan PDRM di bawah Kementerian Dalam Negeri menjadikan warga polis, selaku penjawat awam dan pegawai polis tertakluk kepada peruntukan perundangan dan peraturan berikut secara serentak, iaitu Peraturan-peraturan Pegawai Awam (Kelakuan dan Tatatertib) 1993 (P.U.(A) 395/1993), Perintah Tetap Ketua Polis Negara: A110 - Tatatertib (2017), Akta Polis (1967), Arahan-arahan Pengurusan (Polis Diraja Malaysia 2015), Arahan Pentadbiran (Polis Diraja Malaysia 2010) serta Prosedur Tetap Operasi.

Sebarang bentuk perlakuan, tindakan atau keputusan yang bertentangan dengan peruntukan peraturan, secara fizikal mahupun lisan diistilahkan sebagai melanggar peraturan dan boleh dikenakan tindakan hukuman. Antaranya termasuk membocorkan rahsia kerajaan, mengutamakan kepentingan peribadi, meminta atau menerima rasuah, tidak cekap dan kurang berusaha, pemilikan harta melebihi emolumen, penipuan dan salah guna kuasa (Akauntan Negara Malaysia 2019). Pelanggaran ketetapan sesuatu operasi atau dengan sengaja meninggalkan prosedur kerja juga merupakan suatu kesalahan pelanggaran integriti (Hubert, Pijl dan Steen 1999; Lasthuizen 2008; Six dan Lawton 2013, 5).

Tindakan tatatertib ke atas pelaku tertakluk kepada siasatan dan perbicaraan kes mengikut peruntukan Peraturan-peraturan Lembaga Tatatertib Perkhidmatan Awam 1993 (P.U. (A) 396/1993). Jenis hukuman tertakluk kepada Peraturan 38, P.U. (A) 395/1993 dan direkodkan dalam buku perkhidmatan pelaku. Antaranya hukuman amaran, denda, lucut hak emolumen, tangguh pergerakan, penurunan atau pemotongan gaji, turun pangkat, penahanan kenaikan pangkat dan buang kerja (Akauntan Negara Malaysia 2019). Peraturan dan hukuman mengekang pelaku terus berada dalam organisasi dan menyebarkan pengaruh negatif dalam kalangan warga kerja.

Sejak zaman pemerintahan British hingga pelaksanaan Pelan Integriti Nasional 2004, integriti menjadi tonggak perkhidmatan sektor awam dengan meletakkan kepentingan masyarakat sebagai keutamaan (Anis Yusal dan Mohd Nizam 2016, 69; Veerasamy dan Raja 2014, 151-152). Namun, integriti bakal tergugat apabila tumpuan lebih menjurus kepada kemajuan sosial, pembangunan ekonomi dan inovasi kerana Malaysia di bawah Transformasi Nasional 2021-2050 
mensasarkan matlamat menjadi negara 20 teratas terbaik dunia (Abdul Rahman 2017, 25-26).

Kepesatan sains, teknologi dan globalisasi mewujudkan cabaran getir apabila bidang pekerjaan dan latihan berorientasikan teknologi moden, percambahan pertumbuhan bandar pintar, pertambahan jumlah penduduk dan peningkatan jangka hayat. Hal ini meningkatkan tekanan memenuhi keperluan hidup dengan perolehan gaji yang rendah dan kebergantungan hidup berkerjaya sehingga melakukan pelanggaran integriti seperti rasuah dan salah guna kuasa, jelas Abdul Rahman $(2017,26)$.

Etos perkhidmatan awam (MAMPU 2012), Perintah Tetap Ketua Polis Negara: A110 - Tatatertib (2017) dan Akta Polis (1967) merupakan antara mekanisme kawalan pelanggaran integriti dalam PDRM. Elemen peraturan organisasi dalam Teori Integriti Organisasi Kepolisan (Klockars dan Kutnjak 1999) diaplikasikan dalam kajian integriti organisasi kepolisan di Croatia, Estonia, Rusia, Slovenia, Afrika Selatan, Korea Selatan, Thailand, Amerika Syarikat dan Australia (Kutnjak dan Haberfeld 2015). Mekanisme ini wujud dalam pengimplimentasian integriti di Malaysia, namun belum diaplikasikan dalam kajian integriti di negara ini. Pengaplikasian teori tersebut dalam kajian ini menjadi sumbangan baharu dalam penyelidikan integriti negara.

Selain itu, kajian integriti agensi kepolisan di Croatia (Kutnjak 2015a); Australia (Porter, Prenzler dan Hine 2015); Rusia (Serguei et al. 2015) dan Slovenia (Lobnikar dan Mesko 2015) menunjukkan kepentingan latihan sebagai salah satu teknik kawalan pelanggaran integriti. Di Malaysia, kajian Ruer (2017) serta Ruer dan Hasbee (2016) melihat kepentingan latihan kepolisan dalam meningkatkan pengetahuan, kemahiran dan perubahan sikap warga polis, namun kajian ini memperluaskan bidang kajian dengan menilai keberkesanan latihan melalui pengukuhan amalan integriti dalam kalangan pegawai polis.

Menyoroti kajian sarjana tempatan yang lain, Megat Ayop dan Abdul Halim (2016a; 2016b; 2016c) meneliti kepentingan budaya integriti dan etika kerja dalam PDRM, mengkaji faktor pelanggaran integriti serta kepentingan pemberi maklumat bagi pengukuhan integriti warga PDRM. Sebelum itu, kajian Rohana et al. (2014) mengkaji hubungan kepuasan bekerja dan kod etika terhadap integriti warga PDRM. Manakala kajian Haniza Hanim, Jamaliah dan Zulyanti (2015) pula mengenal pasti tahap integriti dengan mengaplikasikan set soal selidik pengukuran integriti Klockars et al. (2000). 
Kajian Nik Hairi, Azmi dan Azmi (2012) pula membincangkan integriti Jabatan Pengangkutan Jalan berdasarkan rekod pengaduan awam. Manakala kajian Jamaliah, Mad Mahmudul dan Maizatul Akmar (2015), Mohamad Hafiz et al. (2015), Veerasamy dan Raja (2014) dan Mohd Koharuddin et al. (2012) membincang dan menilai amalan integriti sektor awam. Kesimpulannya, terdapat jurang penyelidikan dalam mengenal pasti keberkesanan latihan terhadap integriti warga PDRM.

PDRM terus komited merealisasikan Pelan Integriti PDRM 2016-2020 (Polis Diraja Malaysia 2016). Strategi diatur dengan menitikberatkan aspek latihan dan pembangunan sebagai asas perancangan sumber manusia dan peningkatan produktiviti. Program latihan merupakan medium meningkatkan pengetahuan, kemahiran dan sikap (Wan Idros 2007, 223-225; Gotsch, Keck dan Spencer 2012, 6; Ssonko 2010, 7; Compton et al. 2014a, 518; 2014b, 523). Namun, ketidakcekapan pengurusan program latihan seperti fasilitator yang tidak efektif menggagalkan pencapaian objektif disasarkan (Wan Idros 2007, 225).

Pengetahuan tentang rasuah meningkatkan langkah anti rasuah manakala pengetahuan dan kemahiran tentang pelaksanaan tugas menjadikan polis lebih profesional dan beretika (Dyrmishi et al. 2014, 8 dan 108). Ia membina kapasiti untuk membezakan salah laku, menentang dan mengelakkan rasuah dalam menjalankan tugas. Ruer dan Hasbee $(2016,22)$ serta Ruer $(2017,4)$ menegaskan pegawai polis bukan dilahirkan tetapi dibentuk melalui peningkatan pengetahuan, kemahiran dan sikap menerusi latihan bagi meningkatkan daya kebolehtahanan mental dan fizikal seorang polis untuk menjadi lebih profesional, berintegriti, berdisiplin dan bertanggungjawab.

Dapat dirumuskan daripada sorotan kajian ini bahawa integriti berteraskan kepada elemen nilai-nilai baik, bermoral tinggi dan beretika. Pelanggaran integriti dipengaruhi faktor budaya organisasi dan integriti individu. Elemen latihan menjadi medium utama meningkatkan pemilikan dan amalan integriti pegawai polis. Pengetahuan, kemahiran dan sikap berintegriti membantu mencegah pengaruh terhadap pelanggaran integriti. Walaupun wujud peraturan dan hukuman sebagai pengawalan, namun kes pelanggaran integriti masih berlaku dan tiada kajian ilmiah dibuat setakat ini. Bertepatan jurang tersebut, kajian ini menilai sejauh mana keberkesanan PLAK Kadet Inspektor terhadap amalan integriti dalam kalangan pegawai kanan polis. 


\section{METODOLOGI KAJIAN}

Rajah 1 menunjukkan gambaran keseluruhan metodologi kajian yang menggunakan pendekatan kualitatif dengan reka bentuk kajian kes. Pendekatan ini membolehkan pemerolehan maklumat secara mendalam berdasarkan pengalaman inspektor selepas menjalani PLAK serta telah menjalankan tugas kepolisan. Ia membolehkan fenomena dikaji, difahami dan diperjelaskan dengan lebih tepat menggunakan data primer yang diperoleh menerusi teknik temu bual separa berstruktur dan data sekunder yang melibatkan teknik kajian kepustakaan.

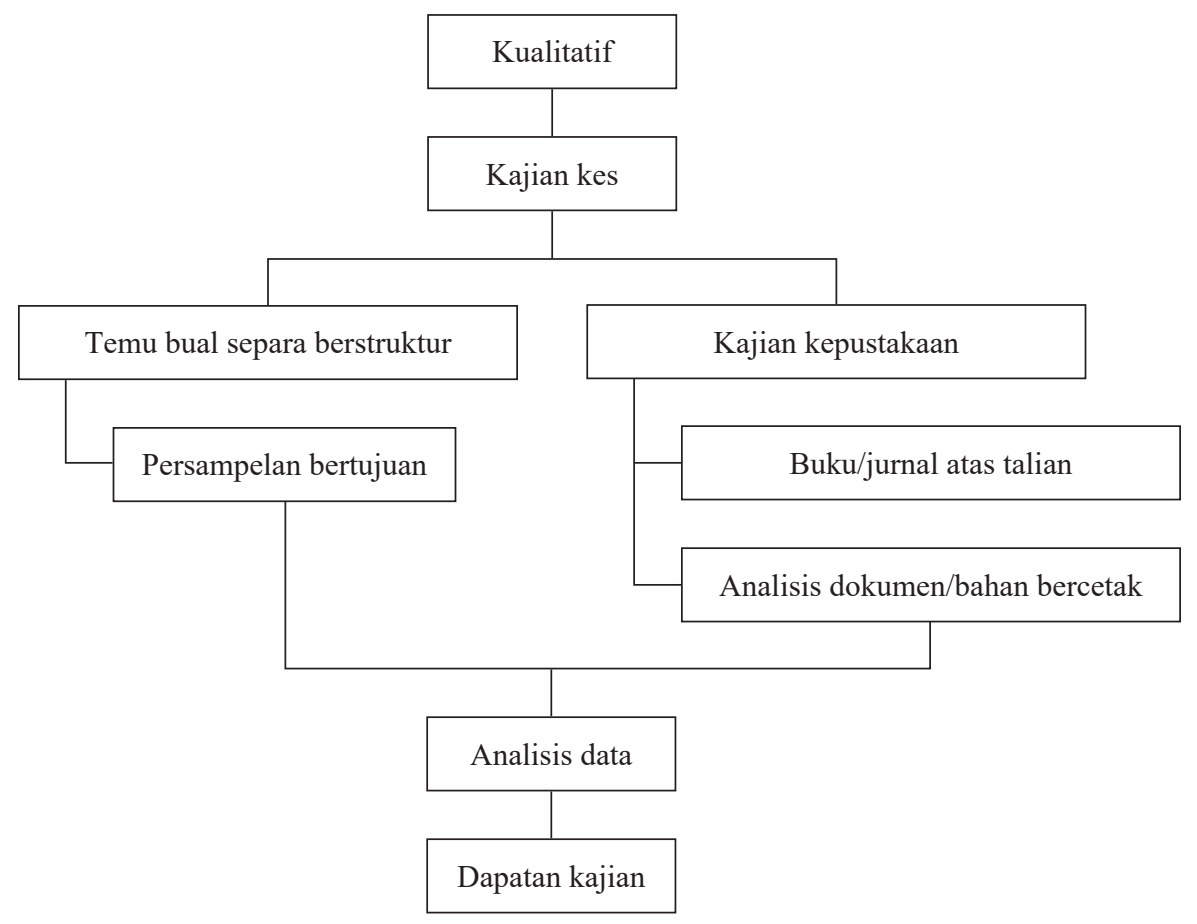

Rajah 1: Reka bentuk kajian.

Kajian ini mengadaptasi kaedah persampelan bertujuan melibatkan tiga aspek iaitu pemilihan informan, lokasi kajian dan jangka masa kajian. Kaedah ini merupakan suatu proses pemilihan berdasarkan kriteria dan perincian yang ditetapkan bagi mencapai objektif kajian. Creswell (2003) menjelaskan pengkaji boleh memilih sampel dan tempat kajian yang dijangka boleh memberi maklumat yang tepat. Thorne, Kirkham dan MacDonald-Ernes (1997), Nina Nurdiani (2014) dan Neuman (2003) menyatakan pemilihan sampel yang mempunyai elemen yang dikongsi bersama dengan sampel yang lain membolehkan perolehan data yang lebih mendalam. Merujuk Rusli et al. (2014), terdapat lima teknik persampelan 
bertujuan dan kajian ini menggunakan judgement sampling iaitu pemilihan berdasarkan tujuan disasarkan.

Kriteria pemilihan informan kajian ini terdiri daripada pegawai polis berpangkat inspektor, telah disahkan jawatan dan tempoh perkhidmatan melebihi tiga tahun. Pemilihan Ibu Pejabat Polis Daerah (IPD) Jempol, Negeri Sembilan sebagai lokasi kajian kerana ia terletak di pusat bandar baharu, Bandar Seri Jempol; mempunyai jaringan perhubungan yang luas dan mudah, kedudukan strategik di pusat pentadbiran daerah, selain berhampiran dengan PULAPOL Ayer Hitam. Ini menunjukkan warga polis IPD Jempol tidak menghadapi masalah untuk mendapatkan latihan. Jangka masa kajian ditetapkan selama satu bulan, mengikut persetujuan pihak pengurusan dan pentadbiran IPD Jempol.

Penggunaan teknik temu bual separa berstruktur melibatkan penetapan soalan lebih awal, boleh diubah suai, ditambah atau diabaikan. Penjelasan secara terus dari informan meningkatkan ketepatan maklumat dan kesahan kajian (Thomson 2011; Robson 2002). Perekodan data menggunakan instrumen soalan temu bual separa berstruktur kerana lebih fleksibel, ruang jawapan yang luas, terbuka dan teratur memberi peluang penerokaan secara lebih mendalam. Sesi temu bual dijalankan mengikut keselesaan informan dari segi masa dan tempat, sekaligus mengurangkan kadar ketidakadilan dalam kajian ini.

Penganalisisan data primer dilaksanakan secara manual, menggunakan perisian Microsoft Office untuk membuat analisis kandungan dan analisis perkaitan. Analisis kandungan melibatkan penciptaan kod-kod mewakili setiap data yang disusun dalam bentuk matrik, melibatkan semakan data, penyusunan data, pembinaan kod, penetapan tema, corak, perkaitan dan akhirnya meringkaskan data (InSites 2007; Shahren 2013). Kod-kod bagi kajian ini seperti tertera di Jadual 2. Manakala tema-tema dalam kajian ini ialah pengisian modul latihan integriti, perubahan pengetahuan, kemahiran dan sikap serta impak pengisian modul latihan terhadap integriti.

Jadual 2: Pembinaan kod

\begin{tabular}{ll}
\hline Kod & Keterangan kod \\
\hline IPD & Ibu Pejabat Polis Daerah \\
PLAK & Program Latihan Asas Kepolisan \\
PULAPOL & Pusat Latihan Polis \\
PDRM & Polis Diraja Malaysia \\
\hline
\end{tabular}

Sumber: Diadaptasi daripada Rusli et al. (2014). 
Sementara itu, pengumpulan data sekunder menerusi kajian kepustakaan melibatkan jurnal dan artikel penyelidikan bidang yang berkaitan. Kaedah ini amat sesuai dan bermanfaat kerana secara relatifnya sangat efektif dari segi kos (Siti Uzairiah 2017). Pemilihan jurnal dan artikel berpandukan kepada beberapa perincian agar tidak tersasar dan kekal signifikan. Selain itu, analisis dokumen melibatkan maklumat data rasmi dari JIPS PDRM turut dilakukan.

Kepelbagaian sumber perolehan data atau triangulasi sumber mengurangkan risiko berlakunya ketidakadilan berbanding penggunaan satu sumber sahaja (Maxwell 2005). Data tepu dicapai apabila pemerolehan data dan maklumat mencukupi, mendalam dan sekata (Fusch dan Ness 2015). Hasil analisis kandungan dan pengekodan mengikut tema ke atas lapan informan mendapati data sudah tepu dan tiada maklumat baharu diperoleh.

\section{SKOP KAJIAN}

Kajian ini menilai keberkesanan latihan terhadap amalan integriti dalam kalangan pegawai polis. Teori Integriti Organisasi Kepolisan mengutarakan empat dimensi bagi memahami konteks integriti warga polis seluruh dunia. Kutnjak (2015b, 4) merujuk Teori Integriti Organisasi Kepolisan (Klockars dan Kutnjak 1999), menjelaskan dimensi berkenaan iaitu peraturan organisasi, teknik kawalan pelanggaran integriti, pengawalan kod senyap serta pengaruh persekitaran sosial dan politik. Dimensi pertama iaitu peraturan organisasi merujuk kepada pembentukan dan pelaksanaan peraturan organisasi agar difahami warganya. Dimensi kedua, teknik kawalan pelanggaran integriti, memfokus kepada kepelbagaian teknik mengawal pelanggaran integriti organisasi dan warganya, seperti penguatkuasaan peraturan, penerapan ilmu etika dan integriti, ujian integriti dan penyiasatan kes pelanggaran integriti. Dimensi ketiga memberi penekanan kepada pengawalan kod senyap kerana pengamalan kod berkenaan menyebabkan pengamalan integriti yang rendah dalam organisasi. Kod senyap menyekat pengaduan atau pelaporan pelanggaran integriti yang berlaku dalam organisasi. Selain itu, dimensi persekitaran politik, ekonomi dan sosial juga ditaksir memberi kesan terhadap integriti organisasi kepolisan tersebut. Dimensi-dimensi berkenaan dilihat mempunyai persamaan dengan konteks kajian ini yang menilai keberkesanan PLAK Kadet Inspektor terhadap amalan integriti pegawai polis.

PLAK menjadi platform mentransformasi individu awam menjadi pegawai polis yang berintegriti, berdisiplin, profesional dan berkeyakinan untuk bertugas selaras dengan misi dan visi pasukan (Ali 2019). Setiap pelatih dilatih untuk 
berazam, berdisiplin, bertanggungjawab, bersemangat, mengamalkan nilai-nilai murni, berintegriti, positif dan berprestasi tinggi melaksanakan tugas kepolisan. Objektif ini selaras dengan objektif kajian yang menjurus kepada amalan integriti dalam kalangan inspektor polis semasa bertugas.

Jelas Wan Idros $(2007,215)$, program latihan yang mirip persekitaran kerja membolehkan pemindahan latihan yang berkesan. Pemilihan sampel dan lokasi kajian ini menepati perincian yang diperlukan untuk pencapaian objektif kajian. Pegawai polis berpangkat inspektor, telah disahkan jawatan, bertugas di IPD Jempol sejak tahun 2015 dipilih sebagai sampel. Tempoh kajian hanya melibatkan tiga tahun iaitu 2015, 2016 dan 2017. Kedudukan IPD Jempol yang strategik dalam lingkungan pusat pentadbiran daerah dan penempatan, mudah diakses, tiada sekatan atau halangan bagi warganya meningkatkan ilmu pengetahuan, kemahiran mahupun sikap menjadi polis berintegriti dan meningkatkan produktiviti organisasi (Azman, Noor Azmi dan Nursaadatun Nisak 2016, 149), sekaligus mengurangkan ketidakadilan terhadap sampel kajian.

\section{KERANGKA TEORI DAN KONSEP}

Kajian ini mengadaptasi Teori Integriti Organisasi Kepolisan (Klockars dan Kutnjak 1999) serta Model Pemindahan Latihan Elangovan dan Karakowsky (Elangovan dan Karakowsky 1999), disintesiskan dengan amalan semasa PDRM iaitu Pelan Integriti PDRM 2016-2020 (Polis Diraja Malaysia 2016) dan PLAK. Hasilnya, selain wujud pengaruh persekitaran sosio politik seperti di Jadual 3, turut dikenal pasti dua konteks utama iaitu integriti dan latihan. Dalam konteks integriti, andaian daripada Teori Integriti Organisasi Kepolisan (Klockars dan Kutnjak 1999) mempunyai persamaan dengan andaian Pelan Integriti PDRM 2016-2020, seperti dalam Jadual 4. Manakala dalam konteks latihan, konsep latihan dalam PLAK direka bentuk seiring dengan konsep pemantapan integriti dalam Pelan Integriti PDRM 2016-2020, seperti di Jadual 5. Selain itu, konsep latihan diaplikasi PDRM dalam PLAK mempunyai persamaan dengan andaian dalam Model Pemindahan Latihan Elangovan dan Karakowsky yang dipaparkan dalam Jadual 6. Persamaan nilai dan elemen daripada teori, model, pelan integriti dan program latihan sedia ada ini merasionalisasikan pembentukan andaian kajian.

\section{Teori Integriti Organisasi Kepolisan}

Teori Integriti Organisasi Kepolisan (Klockars dan Kutnjak 1999, 36), memberi pemahaman bahawa pelanggaran integriti bukan masalah individu, sebaliknya 
mengandaikan empat dimensi mempengaruhi amalan dan tahap integriti agensi kepolisan iaitu peraturan organisasi, teknik kawalan pelanggaran integriti, amalan kod senyap dan pengaruh persekitaran sosio politik. Dimensi peraturan organisasi dan dimensi amalan kod senyap merupakan budaya organisasi kepolisan itu sendiri. Manakala dimensi teknik mengawal perlakuan pelanggaran integriti polis dan pengaruh persekitaran sosio politik lebih terbuka dan luas.

Laporan Suruhanjaya Mollen (Mollen Commission 1994, 63) menjelaskan pegawai polis paling korup tidak menyertai jabatan polis dengan niat untuk menjadi penjenayah, sebaliknya bertekad menjadi pegawai polis yang jujur namun persekitaran mengubah nilai mereka. Dimensi peraturan organisasi memastikan pegawai polis yang jujur terus jujur, melalui pengawasan dan pencegahan melalui kod etika, peraturan disiplin dan pengurusan personal yang berkesan.

Organisasi kepolisan berintegriti tinggi menggunakan pelbagai mekanisme kawalan terhadap perlakuan pelanggaran integriti entitinya. Organisasi tidak bersikap reaktif dengan hanya menjalankan siasatan dan menjatuhkan hukuman, sebaliknya lebih proaktif menerapkan nilai integriti dalam pendidikan atau latihan kakitangan, menjalankan ujian integriti dan penyiasatan proaktif ke atas bakal pegawai polis (Kutnjak, Haberfeld dan Peacock 2015, 6).

Dimensi pengaruh persekitaran sosio politik turut mempengaruhi amalan integriti organisasi kepolisan. Masyarakat membentuk tahap integriti penjawat awam dengan memelihara budaya berintegriti, tidak bertoleransi dengan pelanggaran integriti, meletakkan premium etika yang tinggi, memberi pendidikan, mematuhi peraturan dan bukannya masyarakat yang menggalakkan atau menerima salah laku polis (Kutnjak 2015b, 10). Pengaruh ini diperjelaskan menerusi pengkelasan oleh New York City Police Department, Federal Bureau of Investigation seperti di Jadual 3.

Selain itu, budaya dan amalan kod senyap dalam kalangan warga polis juga menyekat amalan integriti. Kekuatan amalan kod senyap menunjukkan kelemahan amalan integriti, kerana kod senyap merupakan perbuatan mendiamkan perlakuan pelanggaran integriti tanpa membuat sebarang pelaporan.

Andaian teori ini berhubung pengaruh elemen latihan sebagai mekanisme kawalan pelanggaran integriti dilihat mempunyai persamaan dengan kajian ini yang menganalisis keberkesanan latihan terhadap tahap dan amalan integriti warga polis. 
Jadual 3: Pengaruh persekitaran sosio politik terhadap tingkat integriti entiti kepolisan

\begin{tabular}{|c|c|c|}
\hline \multirow{2}{*}{ Masyarakat } & \multicolumn{2}{|c|}{ Agensi kepolisan } \\
\hline & Tinggi integriti & Rendah integriti \\
\hline $\begin{array}{l}\text { Tinggi } \\
\text { integriti }\end{array}$ & $\begin{array}{l}\text { Dalam masyarakat yang menghargai } \\
\text { kelakuan etika penjawat awam, adalah } \\
\text { munasabah mengharapkan agensi polis } \\
\text { mematuhi piawaian yang sama. } \\
\text { Contoh: Polis di Finland dan Sweden. }\end{array}$ & $\begin{array}{l}\text { Masyarakat akan bertindak balas } \\
\text { sekiranya polis tidak melakukan } \\
\text { pembaharuan. } \\
\text { Contoh: Pembaharuan polis } \\
\text { Singapura, New York City Police } \\
\text { Department dalam tahun 1990an. }\end{array}$ \\
\hline $\begin{array}{l}\text { Rendah } \\
\text { integriti }\end{array}$ & $\begin{array}{l}\text { Agensi polis ini akan diberi pengecualian, } \\
\text { ketinggian integriti mereka dari } \\
\text { penentuan pentadbiran dan usaha } \\
\text { tertumpu organisasi. } \\
\text { Contoh: Pembaharuan Federal Bureau } \\
\text { of Investigation semasa pimpinan Hoover } \\
\text { pada tahun 1930an. }\end{array}$ & $\begin{array}{l}\text { Di dalam masyarakat yang tidak } \\
\text { menghargai kelakuan berintegriti } \\
\text { penjawat awam mereka, } \\
\text { adalah munasabah agensi polis } \\
\text { mengikutinya. } \\
\text { Contoh: Agensi polis tempatan } \\
\text { di Mexico, Polis di Pakistan }\end{array}$ \\
\hline
\end{tabular}

Sumber: Kutnjak (2015b).

\section{Pelan Integriti PDRM 2016-2020}

Pelan Integriti PDRM 2016-2020 (Polis Diraja Malaysia 2016) merupakan kesinambungan dari Pelan Integriti PDRM 2007-2010 dan 2010-2015. Pelan ini mensasarkan objektif tiga serangkai iaitu membentuk warga PDRM yang berintegriti ke arah kepolisan moden, menutup ruang dan peluang pelanggaran integriti menerusi pematuhan standard dan etika serta meningkatkan imej, perkhidmatan kepolisan dan profesionalisme warga PDRM. Pelan ini mempunyai enam nilai teras iaitu integriti, bermoral, beretika, keagamaan, kerohanian dan profesionalisme.

Pelan ini memfokuskan kepada lima teras strategik yang digalur untuk meningkatkan integriti warga polis. Lima strategi tersebut ialah memantapkan pengurusan pentadbiran dan pematuhan standard, meningkatkan keberkesanan sistem perkhidmatan penyampaian, memantapkan pengurusan sumber manusia, memperkasakan imej PDRM ke arah kepolisan moden serta mensejahterakan institusi keluarga. Antara gerak kerja pelaksanaan strategi termasuk mengkaji semula saringan pengambilan pelatih baru, meningkatkan pengetahuan dan kemahiran sistem teknologi maklumat, melaksanakan modul pemantapan integriti dalam program latihan asas, kursus dan latihan dalam perkhidmatan serta memperkasakan pematuhan etika dan istiadat kepolisan. Pelan ini mengandaikan bahawa integriti warga polis boleh dipertingkatkan 
menerusi strategi dan gerak kerja tersebut yang jelas mempunyai persamaan dengan andaian Teori Integriti Organisasi Kepolisan seperti di Jadual 4.

Jadual 4: Sintesis andaian Teori Integriti Organisasi Kepolisan dengan Pelan Integriti PDRM 2016-2020

\begin{tabular}{|c|c|c|}
\hline $\begin{array}{l}\text { Andaian Teori Integriti } \\
\text { Organisasi Kepolisan }\end{array}$ & $\begin{array}{l}\text { Andaian Pelan Integriti PDRM } \\
\text { 2016-2020 }\end{array}$ & Kesepaduan nilai \\
\hline $\begin{array}{l}\text { Mengandaikan bahawa } \\
\text { penetapan kod etika, peraturan } \\
\text { disiplin, pengurusan personal } \\
\text { dan peruntukan undang- } \\
\text { undang tatakelakuan menjadi } \\
\text { mekanisme pengawalan dan } \\
\text { pencegahan. }\end{array}$ & $\begin{array}{l}\text { Pemantapan aspek pengurusan } \\
\text { pentadbiran dan pematuhan } \\
\text { standard menerusi penguatkuasaan } \\
\text { Akta Polis (1967), Perintah Tetap } \\
\text { Ketua Polis Negara: A110 - } \\
\text { Tatatertib (2017), Skim Kawalan } \\
\text { Dadah dan Disiplin (2017) dan } \\
\text { Peraturan-peraturan Pegawai Awam } \\
\text { (Kelakuan \& Tatatertib) (1993). }\end{array}$ & Peraturan organisasi. \\
\hline $\begin{array}{l}\text { Pelaksanaan pelbagai } \\
\text { program atau mekanisme } \\
\text { secara proaktif mampu } \\
\text { mengekang, mengesan, } \\
\text { mengawal dan menyelesaikan } \\
\text { isu pelanggaran integriti. }\end{array}$ & $\begin{array}{l}\text { Mempromosikan Pelan Integriti } \\
\text { PDRM dan etos perkhidmatan } \\
\text { awam (2012). } \\
\text { Menerapkan Modul Integriti } \\
\text { Agensi Penguatkuasaan (2016) } \\
\text { dalam PLAK. } \\
\text { Pengkhususan JIPS yang } \\
\text { bertanggungjawab menyiasat, } \\
\text { menjatuhkan hukuman dan } \\
\text { mengadakan program kekeluargaan, } \\
\text { kejiranan, gaya hidup sihat dan } \\
\text { kerohanian yang mengekang } \\
\text { pelanggaran integriti dalam } \\
\text { kalangan warga polis. }\end{array}$ & $\begin{array}{l}\text { Kepelbagaian teknik } \\
\text { atau mekanisme } \\
\text { kawalan pelanggaran } \\
\text { integriti. }\end{array}$ \\
\hline $\begin{array}{l}\text { Pengawalan dan pengurangan } \\
\text { amalan budaya kod } \\
\text { senyap dalam organisasi } \\
\text { meningkatkan amalan integriti } \\
\text { warga polis. }\end{array}$ & $\begin{array}{l}\text { Meningkatkan kesedaran, } \\
\text { memberi anugerah ikon integriti, } \\
\text { melantik lebih ramai pegawai } \\
\text { integriti bertauliah (CeIO) dan } \\
\text { meningkatkan pelindungan pemberi } \\
\text { maklumat boleh meningkatkan } \\
\text { integriti PDRM. }\end{array}$ & $\begin{array}{l}\text { Penolakan dan } \\
\text { pengurangan budaya } \\
\text { kod senyap. }\end{array}$ \\
\hline $\begin{array}{l}\text { Persekitaran sosio politik } \\
\text { memberi kesan terhadap } \\
\text { amalan integriti warga polis }\end{array}$ & $\begin{array}{l}\text { Meningkatkan program pengurusan } \\
\text { institusi keluarga, amalan gaya } \\
\text { hidup sihat, amalan hijau dan } \\
\text { kebajikan warga polis. }\end{array}$ & $\begin{array}{l}\text { Kewujudan pengaruh } \\
\text { sosial, ekonomi dan } \\
\text { politik terhadap } \\
\text { integriti warga polis. }\end{array}$ \\
\hline
\end{tabular}

Sumber: Diadaptasi daripada Kutnjak dan Haberfeld (2015) dan Pelan Integriti PDRM 2016-2020 (Polis Diraja Malaysia 2016). 


\section{PLAK Kadet Inspektor}

Bahagian Latihan, Jabatan Pengurusan PDRM bertanggungjawab sepenuhnya mengkaji, merangka, menyusun, melaksana dan mengawal selia PLAK agar sejajar dengan Pelan Integriti PDRM 2016-2020 (Polis Diraja Malaysia 2016) bagi mencapai misi dan visi PDRM (Jabatan Pengurusan PDRM 2006). Merujuk Pusat Latihan Polis (2017), PLAK berorientasikan pemikiran dan mentransformasikan fizikal serta tingkah laku seorang awam menjadi pegawai polis berintegriti. PLAK meliputi latihan asas kepolisan, kecergasan fizikal, kepimpinan, pengendalian operasi, pengetahuan undang-undang, kemahiran teknologi maklumat, urus tadbir, kemahiran menembak, pengetahuan agama dan kenegaraan. Silibus ini seragam bagi setiap peringkat PLAK sama ada konstabel, kadet sarjan dan kadet inspektor di semua lapan pusat latihan seluruh negara. Corak pembelajaran PLAK turut menguatkuasakan hukuman "double kawad" dan "command barrack" bagi pelanggaran peraturan, arahan dan disiplin oleh pelatih.

PLAK bersifat holistik, selari dengan keperluan penugasan semasa, bahkan turut mempunyai Pusat Simulasi Taktikal yang memberi latihan menggunakan teknik experiential learning. Rakan pintar Strategi Lautan Biru, kolaborasi PDRM dengan Institut Tadbiran Awam Negara (INTAN) menggunakan pelantar E-Pembelajaran Sektor Awam (EPSA) mengetengahkan tiga modul iaitu kepolisan komuniti, hak asasi manusia dan integriti. Selain itu, Modul Integriti Agensi Penguatkuasaan (Mohammad Diah dan Harisham 2016) turut diimplimentasikan dalam silibus PLAK, meliputi sub-modul iaitu penjagaan imej agensi penguatkuasaan, pengurusan kewangan pegawai penguatkuasa, membetulkan yang biasa membiasakan yang betul, kerja sebagai satu ibadah dan menginstitusikan integriti. Pelaksanaan modul dipelbagaikan agar lebih interaktif sejajar dengan matlamat untuk membudayakan integriti.

PLAK berandaian generasi polis berintegriti boleh dilahirkan menerusi pembelajaran dan latihan yang meningkatkan ilmu pengetahuan, kemahiran dan sikap. Andaian ini mempunyai persamaan dengan Pelan Integriti PDRM 20162020 yang mengiktiraf latihan sebagai mekanisme meningkatkan tahap integriti warga PDRM seperti Jadual 5. 
Jadual 5: Sintesis PLAK dengan Pelan Integriti PDRM 2016-2020

\begin{tabular}{ll}
\hline \multicolumn{1}{c}{ Pelan Integriti PDRM 2016-2020 } & \multicolumn{1}{c}{ PLAK } \\
\hline $\begin{array}{l}\text { Memantapkan pengurusan pentadbiran dan } \\
\text { pematuhan standard menerusi penguatkuasaan }\end{array}$ & $\begin{array}{l}\text { Disediakan slot khas Pelan Integriti } \\
\text { peraturan Perintah Tetap Ketua Polis Negara: } \\
\text { A110 - Tatatertib dan mempromosikan Pelan } \\
\text { Integriti PDRM. }\end{array}$ \\
$\begin{array}{l}\text { Memantapkan dilaksanakan penguatkuasaan } \\
\text { pematuhan peraturan serta hukuman } \\
\text { sepanjang tempoh PLAK. }\end{array}$ \\
$\begin{array}{l}\text { mengkaji semula tapisan pengambilan pelatih } \\
\text { dengan komponen integriti, melaksanakan modul } \\
\text { pemantapan integriti, memperkasakan pematuhan } \\
\text { etika serta istiadat kepolisan semasa latihan asas. }\end{array}$ & $\begin{array}{l}\text { Pelaksanaan ujian integriti semasa } \\
\text { dalam tempoh pelaksanaan PLAK, } \\
\text { disediakan slot pembelajaran modul } \\
\text { integriti dalam jadual pembelajaran }\end{array}$ \\
$\begin{array}{l}\text { Memperkasakan imej PDRM ke arah kepolisan } \\
\text { moden dengan meningkatkan kesedaran, }\end{array}$ & $\begin{array}{l}\text { PLAK setiap minggu. } \\
\text { pendidikan dan pencegahan rasuah dalam }\end{array}$ \\
kalangan warga PDRM. & syarahan tentang gejala rasuah \\
\hline
\end{tabular}

Sumber: Diadaptasi daripada Prospektus PULAPOL Kuala Lumpur (Pusat Latihan Polis 2017) dan Pelan Integriti PDRM 2016-2020 (Polis Diraja Malaysia 2016).

\section{Model Pemindahan Latihan}

Latihan ialah pelaburan jangka panjang organisasi bagi meningkatkan produktiviti, tahap guna tenaga dan keuntungan organisasi semasa dan masa hadapan (Balkisnah dan Norhasni 2009, 108; Tate 1995, 102; Wan Idros 2001, 98-99; Maizatul 2002, 148; Bulgarelli dan Gori 2004, 231; Kamaruzzaman, Shuhaida dan Bahiyah 2013, 32). Pekerja lebih berkeyakinan untuk bekerja setelah mengikuti latihan (Abdul Rahim dan Shamsiah 2008, 10; Easdown 1994, 75; Kamaruzzaman, Shuhaida dan Bahiyah 2013, 35), namun tidak dijamin pengaplikasian kerana bergantung kepada keyakinan untuk menggunakannya (Azlah et al. 2009, 65). Proses pemindahan latihan yang positif mempengaruhi pelatih menggunakan pengetahuan, kemahiran dan sikap yang diperoleh ke alam pekerjaan (Newstrom 1986, 155). Balkisnah dan Norhasni (2009, 115) membincangkan pelbagai model pemindahan latihan yang merungkai faktorfaktor yang mempengaruhi proses berkenaan. Kurangnya perhatian kepada proses pemindahan latihan menyebabkan kegagalan mengenal pasti isu-isu penting berkaitan keberkesanan latihan dan pemindahan latihan (Elangovan dan Karakowsky 1999, 268).

Kajian ini mengadaptasi Model Pemindahan Latihan Elangovan dan Karakowsky seperti di Rajah 2. Model ini menghuraikan hubungan antara program latihan pekerja dengan perlakuan di tempat kerja, berandaian bahawa transaksi 
pemindahan ilmu pengetahuan, kemahiran dan sikap dari program latihan dipengaruhi faktor individu dan faktor persekitaran (Elangovan dan Karakowsky 1999, 270). Faktor individu dicirikan oleh faktor motivasi dan faktor keupayaan, manakala faktor persekitaran kerja, dicirikan dengan faktor kerja dan faktor organisasi.

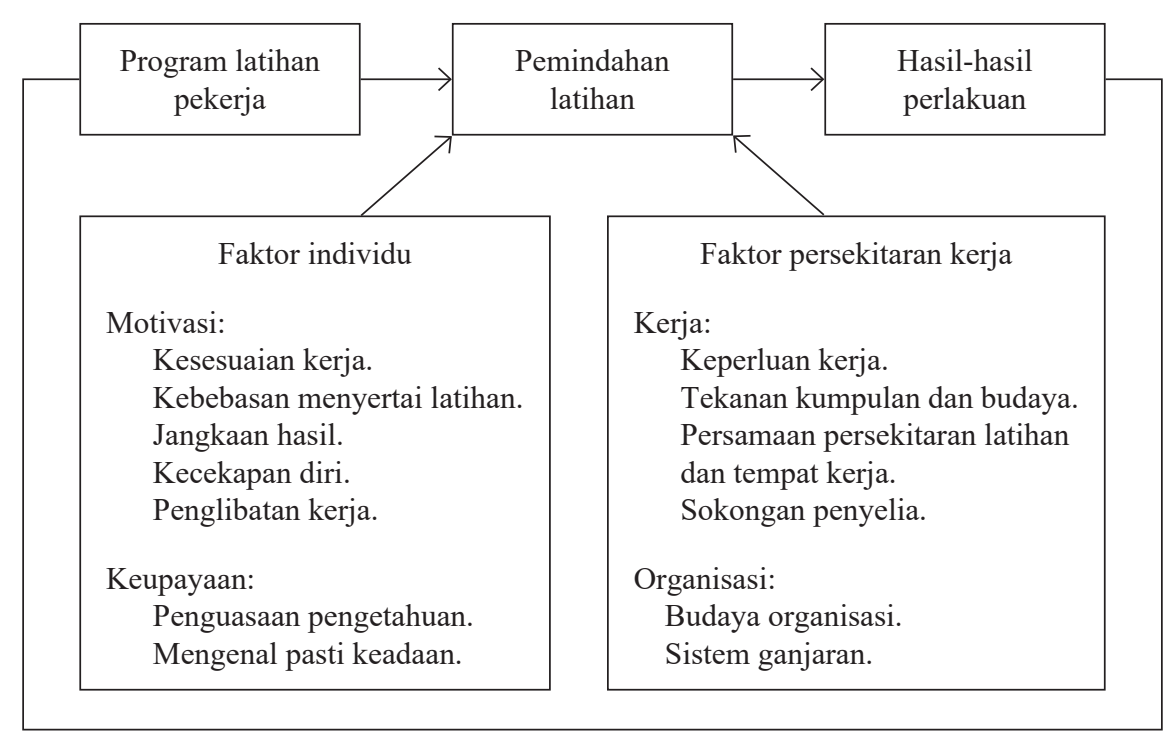

Rajah 2: Model Pemindahan Latihan Elangovan dan Karakowsky. Sumber: Elangovan dan Karakowsky (1999).

Keempat-empat faktor tersebut mempunyai sub-elemennya tersendiri. Faktor motivasi pekerja diperincikan oleh sub-elemen kesesuaian kerja, kebebasan menyertai latihan, jangkaan hasil, kecekapan diri dan penglibatan kerja. Manakala, elemen penguasaan pengetahuan dan mengenal pasti keadaan menjadi penentu kekuatan faktor keupayaan. Sementara itu, faktor kerja dicirikan oleh sub-elemen keperluan kerja, tekanan kumpulan dan budaya, persamaan persekitaran latihan dan tempat kerja serta sokongan penyelia. Manakala elemen budaya organisasi dan sistem ganjaran yang diamalkan organisasi menjadi perincian faktor organisasi yang turut mempengaruhi pekerja untuk mempraktikkan pengetahuan, kemahiran dan sikap dari latihan kepada kelakuan di tempat kerja. Andaian model ini mempunyai persamaan dengan andaian PLAK, sebagaimana dalam Jadual 6. 
Jadual 6: Sintesis Andaian Model Pemindahan Latihan Elangovan dan Karakowsky dengan PLAK

\begin{tabular}{|c|c|c|}
\hline $\begin{array}{l}\text { Model Pemindahan Latihan } \\
\text { Elangovan dan Karakowsky }\end{array}$ & Pengisian PLAK & Kesepaduan nilai \\
\hline $\begin{array}{l}\text { Mengandaikan bahawa } \\
\text { pemindahan latihan } \\
\text { dipengaruhi faktor } \\
\text { persekitaran kerja. }\end{array}$ & $\begin{array}{l}\text { Mengandaikan pemahaman persekitaran } \\
\text { tempat kerja semasa menjalani latihan } \\
\text { meningkatkan kemampuan mengadaptasi } \\
\text { atau pemindahan latihan ke tempat kerja. }\end{array}$ & $\begin{array}{l}\text { Kepentingan } \\
\text { mengadaptasi } \\
\text { persekitaran kerja. }\end{array}$ \\
\hline
\end{tabular}

Sumber: Diadaptasi daripada Elangovan dan Karakowsky (1999) dan PLAK.

Secara keseluruhan, wujud persamaan nilai antara Teori Integriti Organisasi Kepolisan, Pelan Integriti PDRM 2016-2020, PLAK serta Model Pemindahan Latihan Elangovan dan Karakowsky berhubung aspek latihan, pematuhan standard dan peraturan organisasi, persekitaran sosial, politik dan ekonomi serta persekitaran tempat kerja memberi kesan terhadap amalan integriti warga polis. Ia juga dilihat selari dengan objektif kajian. Secara sintesisnya, andaianandaian yang mendasari teori, model dan konsep berkenaan membawa kepada pembentukan andaian bagi kajian ini iaitu pegawai polis berintegriti boleh dilahirkan menerusi pengisian modul latihan integriti dalam PLAK dan diterjemahkan ke alam penugasan secara berterusan seperti Jadual 7.

Jadual 7: Sintesis andaian antara Teori Integriti Organisasi Kepolisan, Pelan Integriti PDRM 2016-2020, PLAK, Model Pemindahan Latihan Elangovan dan Karakowsky dan andaian kajian

Teori Integriti Organisasi

Kepolisan

Pelan Integriti PDRM

2016-2020

PLAK

Model Pemindahan

Latihan Elangovan

dan Karakowsky

Andaian kajian
Integriti warga polis dipengaruhi empat dimensi luaran, termasuk elemen peraturan organisasi dan latihan sebagai mekanisme kawalan pelanggaran integriti.

Pemantapan pengurusan sumber manusia menerusi latihan dan pematuhan standard menerusi penguatkuasaan peraturan organisasi boleh meningkatkan integriti warga polis.

Latihan meningkatkan pengetahuan, kemahiran dan sikap bagi melahirkan warga PDRM yang berintegriti dan memiliki sahsiah kepolisan moden.

Aspek latihan, pematuhan standard dan peraturan organisasi, persekitaran sosial, politik dan ekonomi serta persekitaran tempat kerja memberi kesan terhadap amalan integriti warga polis.

Pegawai polis berintegriti boleh dilahirkan menerusi pengisian modul integriti dalam PLAK dan diterjemahkan ke alam penugasan secara berterusan.

Sumber: Diadaptasi daripada Teori Integriti Organsasi Kepolisan, Pusat Latihan Polis (2017), Pelan Integriti PDRM 2016-2020 (Polis Diraja Malaysia 2016) dan Model Pemindahan Latihan Elangovan dan Karakowsky. 
Berteraskan kepada andaian tersebut, Rajah 3 menggambarkan andaian Model Polis Berintegriti.

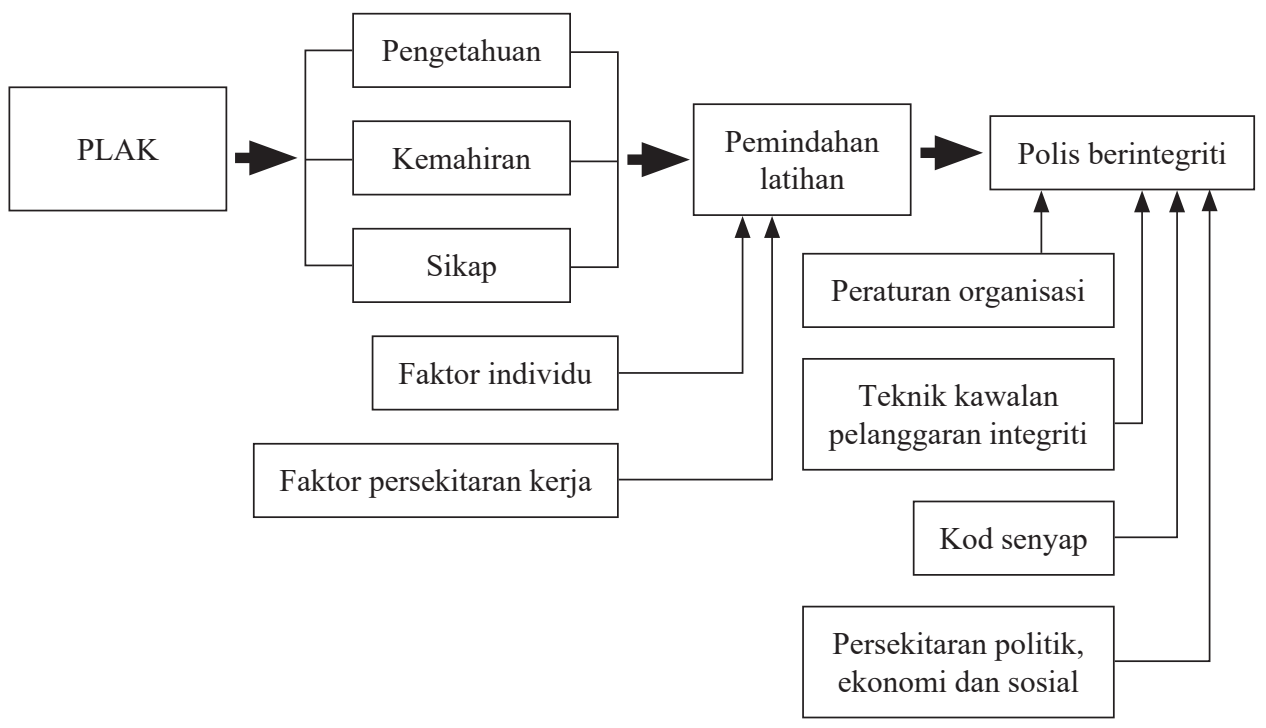

Rajah 3: Andaian Model Polis Berintegriti.

Sumber: Diadaptasi daripada Teori Integriti Organisasi Kepolisan, Pelan Integriti PDRM 2016-2020, PLAK dan Model Pemindahan Latihan Elangovan dan Karakowsky.

\section{DAPATAN KAJIAN DAN PERBINCANGAN}

Perolehan data primer dan data sekunder menunjukkan faktor modul latihan mendominasi pengaruh dan menjadi pemangkin keberkesanan latihan terhadap amalan integriti dalam kalangan pegawai polis. Faktor persekitaran tempat kerja dan keluarga turut memberi impak tersendiri. Data mencapai tahap tepu apabila kesemua informan menyebut perkara yang sama iaitu modul latihan, persekitaran tempat kerja dan pengaruh keluarga mempengaruhi pemindahan pengetahuan, kemahiran dan sikap berintegriti seorang pegawai polis yang diperoleh dari PLAK sebagai amalan di tempat kerja. Kajian mencapai objektif yang disasarkan, malah andaian kajian juga berjaya dibuktikan dan menemui dapatan baru iaitu faktor keluarga sebagai pemboleh ubah yang mempengaruhi amalan integriti warga polis dalam pelaksanaan penugasan mereka. 


\section{Pengisian Modul Latihan Integriti PLAK}

Menerusi data sekunder yang dikenal pasti, modul PLAK Kadet Inspektor didapati meliputi aspek pengetahuan, kemahiran dan pembentukan sikap kepolisan moden yang berintegriti. Penerapan modul peraturan organisasi, peruntukan undang-undang, prosedur kerja dan integriti meningkatkan ilmu pengetahuan kepolisan. Kemahiran berkomunikasi, kawad, menembak, senaman dan tae kwan do merupakan antara aspek kemahiran diterapkan dalam PLAK (Pusat Latihan Polis 2017). Penerapan modul-modul berkenaan membawa kepada perubahan sikap berintegriti seperti kepatuhan kepada peraturan dan arahan, berdisiplin, menepati masa dan akur dengan ketetapan organisasi.

Data sekunder diperkukuhkan dengan lapan kenyataan daripada kesemua informan bahawa modul latihan PLAK ialah modul integriti kerana padat dengan pengisian yang membentuk serta memantapkan integriti individu. Antara modul tersebut ialah modul undang-undang, kepimpinan, peraturan organisasi, kemahiran kawad dan menembak, mempunyai nilai integriti kepatuhan kepada peraturan, arahan ketua dan arahan organisasi. Informan 3 mengklasifikasikan pelaksanaan hukuman bagi salah laku mempunyai nilai integriti iaitu menerima kesilapan diri dan akur tindakan organisasi. Tambah Informan 5, penerapan modul integriti telah sedia ada dalam PLAK kerana terdapat silibus khusus tentang integriti.

Rajah 4 merupakan ilustrasi dapatan kajian yang menunjukkan pencapaian objektif kajian untuk mengenal pasti pengisian program latihan dalam PLAK. Pengisian berkenaan mencakupi peningkatan aspek pengetahuan, kemahiran dan sikap ke arah melahirkan pegawai polis berintegriti. Dapatan ini mengesahkan andaian kajian bahawa pegawai polis berintegriti boleh dilahirkan menerusi pengisian modul integriti PLAK. Nilai ini mempunyai persamaan dengan andaian teori, model dan konsep yang mendasari kajian ini, iaitu latihan serta pengisian modul latihan sebagai suatu mekanisme kawalan pelanggaran integriti juga menjana peningkatan amalan integriti dalam kalangan warga PDRM. Kesimpulannya, triangulasi data primer dan data sekunder menunjukkan modul latihan dalam PLAK merupakan modul latihan integriti iaitu faktor dominan yang mempengaruhi amalan integriti warga polis. 


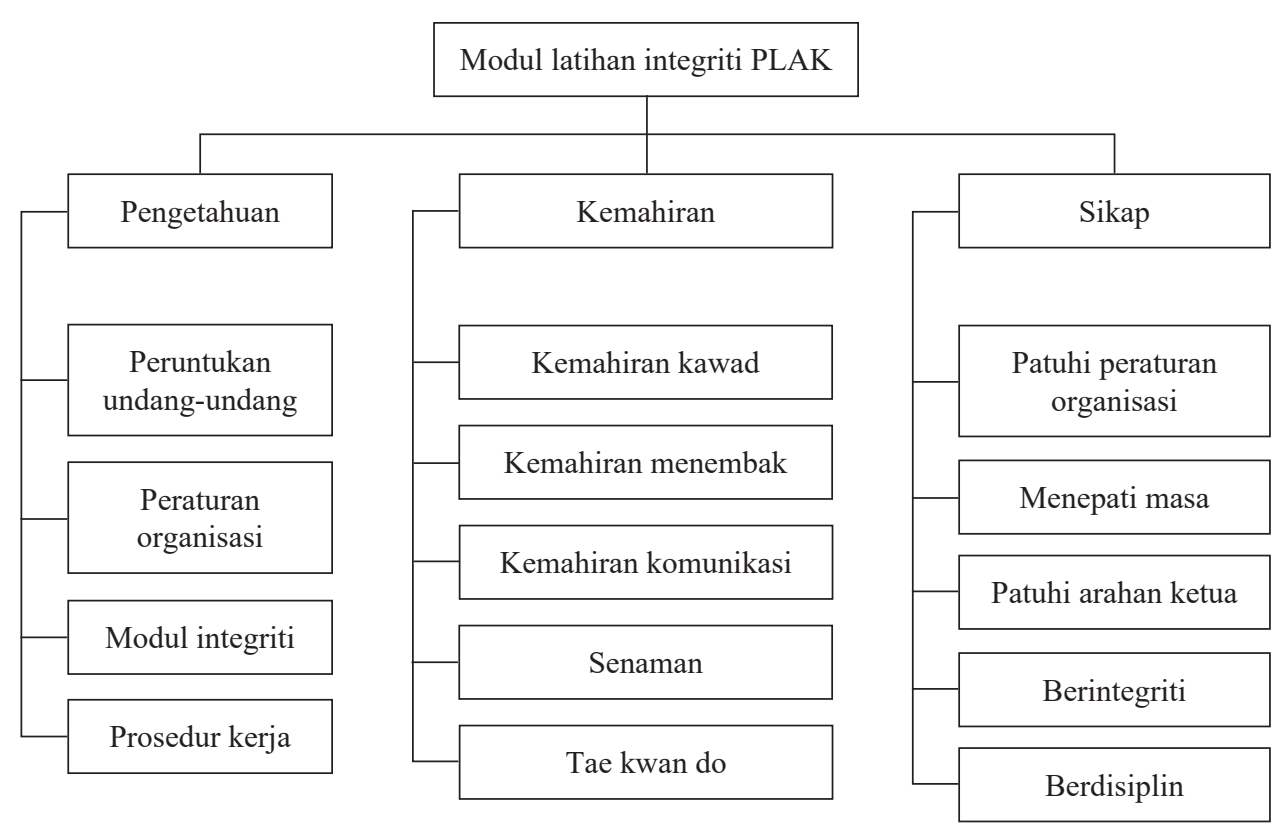

Rajah 4: Modul latihan integriti PLAK.

Sumber: Kajian lapangan (2017).

\section{PLAK Melahirkan Polis Berintegriti}

PLAK merupakan pelaburan besar PDRM, mentransformasi orang awam menjadi pegawai polis yang mendaulatkan undang-undang, menjaga keselamatan dan mengekalkan ketenteraman awam (Ali 2018). Modul latihan integriti PLAK dibentuk dan disusun agar dapat melahirkan pegawai polis kadet inspektor yang berintegriti, berketerampilan dan profesional. Pengisian modul latihan PLAK yang holistik mencakupi aspek pengetahuan, kemahiran dan sikap berintegriti mengoptimumkan keberkesanan PLAK (Pusat Latihan Polis 2017).

Data primer daripada lapan informan mendapati sebanyak 47 kenyataan memperakui modul latihan integriti PLAK meningkatkan pengetahuan, kemahiran dan sikap berintegriti. Rajah 5 memaparkan pecahan dapatan kajian berhubung pembelajaran yang diperoleh dari PLAK. 


\section{Pembelajaran dari PLAK}

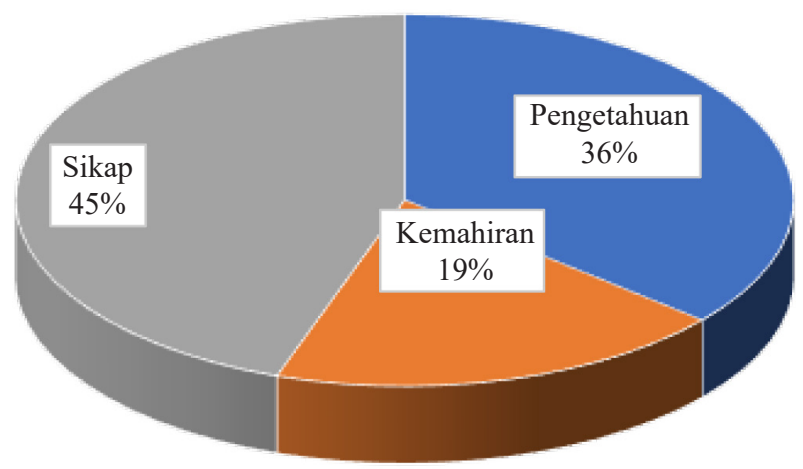

Rajah 5: Pecahan pembelajaran dari PLAK.

Hasil kajian menunjukkan pembelajaran dari PLAK lebih menjurus kepada perubahan sikap atau transformasi diri individu awam menjadi pegawai polis iaitu dengan 21 kenyataan (45\%), melibatkan perubahan sikap berdisiplin (8 kenyataan), kepatuhan kepada undang-undang (8 kenyataan) dan berintegriti (5 kenyataan). Peratusan 36\% mewakili 17 kenyataan informan menyatakan pembelajaran PLAK membawa peningkatan ilmu pengetahuan bidang kepolisan mencakupi perundangan Malaysia, peraturan organisasi, prosedur kerja dan integriti. Selain itu, 9 kenyataan diwakili 19\% menyatakan pembelajaran PLAK membawa perubahan kemahiran meliputi kemahiran menembak, kawad dan berkomunikasi.

Sementara itu, Rajah 6 menggambarkan proses transformasi individu awam menjadi pegawai polis berintegriti menerusi modul latihan integriti PLAK yang menghasilkan peningkatan pengetahuan, kemahiran dan perubahan sikap. Dapatan ini memperkukuhkan lagi andaian kajian bahawa modul latihan integriti mampu melahirkan pegawai polis berintegriti. Malah turut menepati andaian Teori Integriti Organisasi Kepolisan iaitu latihan sebagai salah satu mekanisme teknik kawalan pelanggaran integriti. 


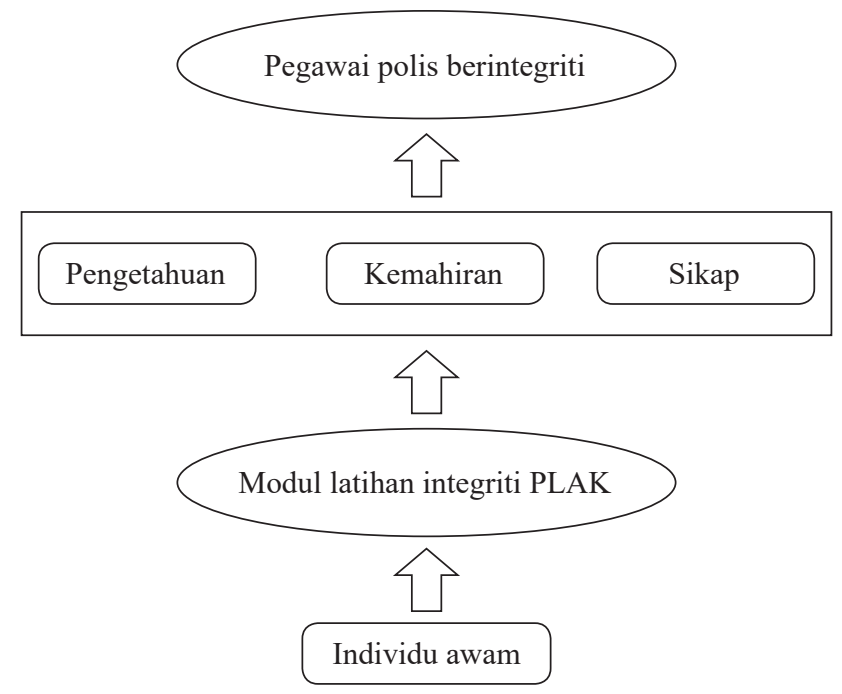

Rajah 6: Proses transformasi individu awam menjadi pegawai polis berintegriti.

\section{Kesan Pengisian Modul Latihan Integriti PLAK Terhadap Amalan Integriti}

Walaupun semua informan memperakui bahawa pengisian modul latihan integriti PLAK meningkatkan pengetahuan, kemahiran dan perubahan sikap berintegriti, namun ia tidak menjamin pengaplikasiannya di alam pekerjaan (Newstrom 1986; Azlah et al. 2009). PLAK lebih menjurus kepada pulangan jangka masa panjang. Justeru, kajian keberkesanan latihan diperhalusi dengan menganalisis proses pemindahan pengetahuan, kemahiran dan sikap dari PLAK ke alam pekerjaan. Dapatan kajian menunjukkan perbezaan ketara dengan perangkaan statistik pelanggaran integriti (Jabatan Integriti dan Pematuhan Standard 2019) yang merekodkan peningkatan jumlah penglibatan pegawai polis berpangkat inspektor melakukan pelanggaran integriti, sekaligus memperkukuhkan rasionalisasi dan kerelevanan kajian ini.

Bagi mengenal pasti keberkesanan PLAK, maklum balas semua informan dianalisis. Pemindahan latihan dari PLAK ke tempat kerja dikaji berdasarkan skop pembelajaran meliputi aspek pengetahuan, kemahiran dan sikap. Dapatan kajian menunjukkan informan merumuskan kepentingan pemindahan latihan ke tempat kerja adalah untuk pelaksanaan penugasan. Skala pemindahan latihan sebagai amalan di tempat kerja dilihat agak setara bagi ketiga-tiga aspek sebagaimana diilustrasikan dalam Rajah 7 di mana semua aspek pembelajaran iaitu pengetahuan, kemahiran dan sikap mendapat maklum balas seimbang. 


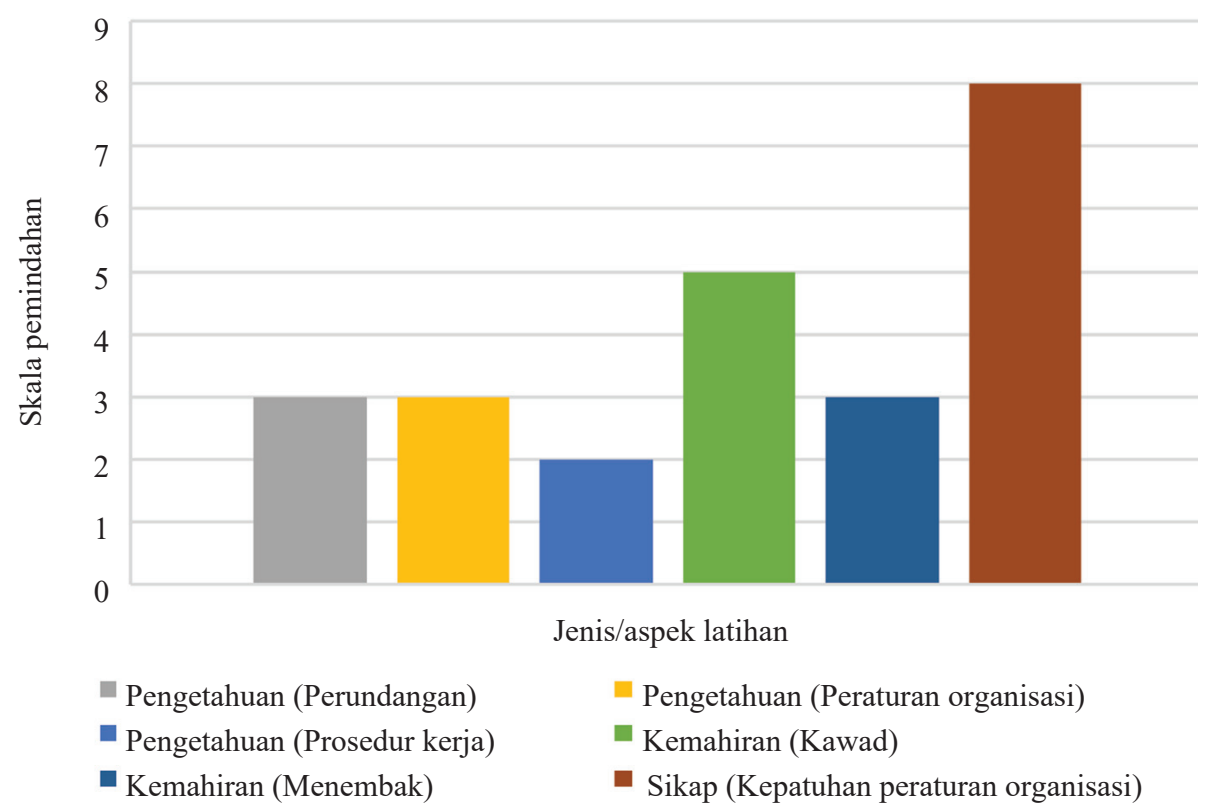

Rajah 7: Pemindahan latihan ke tempat kerja.

Pemindahan aspek pengetahuan meliputi bidang perundangan (3 kenyataan), peraturan organisasi (3 kenyataan) dan prosedur kerja (2 kenyataan). Kenyataan Informan 3 menjelaskan pemindahan berkenaan iaitu "PLAK tingkatkan pengetahuan perundangan untuk keperluan pengklasifikasian kes, prosedur siasatan".

Pemindahan aspek kemahiran dari PLAK ke tempat kerja pula melibatkan kemahiran kawad (5 kenyataan) dan kemahiran menembak (3 kenyataan). Kenyataan Informan 3 menjelaskan kemahiran yang dipelajari dan dipraktikkan, "kemahiran kawad sentiasa dipraktikkan dalam tempoh bekerja." Sementara Informan 5 juga turut menyatakan perkara yang sama, "PLAK beri kemahiran baru iaitu kawad dan menembak".

Demikian juga pemindahan atau pengekalan sikap yang terbentuk menerusi PLAK ke tempat kerja. Lapan informan menjurus kepada sikap kepatuhan kepada peraturan organisasi. Selain itu, Informan 2, Informan 6 dan Informan 8 turut menyatakan impak pembelajaran PLAK masing-masing, "perubahan sikap lebih berdisiplin", "ubah sikap lebih patuh kepada peraturan dan undang-undang" dan "sikap berdisiplin patuh gaya potongan rambut dan pemakaian pakaian seragam". 
Mendalami kesan pengisian program latihan integriti terhadap amalan integriti pegawai polis, pandangan dan pendapat informan berhubung faktor-faktor yang mempengaruhi pengadaptasian atau pengamalan pengetahuan, kemahiran dan sikap dari PLAK ke alam pekerjaan dikumpul. Rumusannya, faktor modul latihan mendominasi pengaruhnya selain faktor persekitaran tempat kerja dan faktor keluarga memberi impak masing-masing terhadap keberkesanan program latihan melalui amalan integriti dalam kalangan pegawai polis (rujuk Rajah 8).

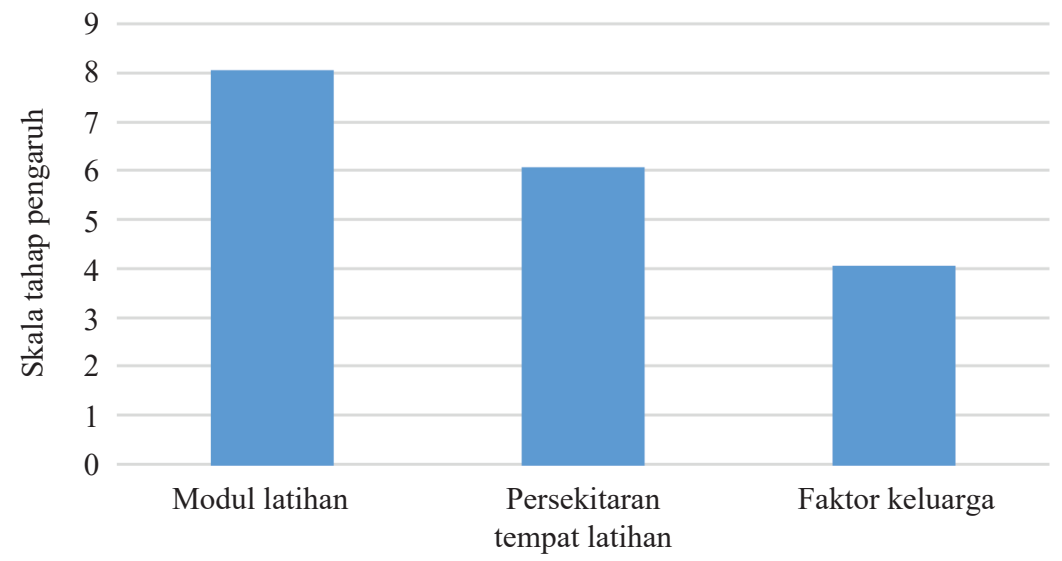

Rajah 8: Faktor-faktor yang mempengaruhi keberkesanan latihan.

Kesemua lapan informan menyatakan faktor modul latihan mempengaruhi keberkesanan latihan dan impaknya terhadap amalan integriti dalam kalangan pegawai polis. Informan 1 , Informan 4 dan Informan 7 masing-masing menyatakan pendapat seperti, "modul latihan sangat mempengaruhi keberkesanan latihan", "untuk berintegriti dalam penugasan, pengisian program latihan perlu berintegriti" dan "penugasan berintegriti ditentukan oleh modul latihan berintegriti”.

Selain itu, enam informan turut menyatakan faktor persekitaran tempat kerja mempunyai pengaruh terhadap amalan dan pengadaptasian pengetahuan, kemahiran dan sikap berintegriti di tempat kerja, seperti kenyataan oleh Informan 3 iaitu "ilmu dari latihan tidak akan diadaptasi atau diamalkan sebab suasana persekitaran tempat kerja tidak menggalakkan". Manakala Informan 5 dan Informan 8 turut bersetuju dengan menyatakan pendapat masing-masing, "suasana tempat kerja pengaruhi sikap tidak berintegriti" dan "persekitaran tempat kerja sekat amal sikap integriti". 
Sementara itu, seramai empat informan lain telah menyenaraikan faktor keluarga sebagai faktor yang turut memberi impak negatif terhadap proses pemindahan latihan berkenaan. Antara kenyataan tersebut ialah "fokus keluarga terhadap kemewahan pengaruh sikap tidak berintegriti polis" (Informan 1), "perbelanjaan keluarga melebihi pendapatan desak polis tidak berintegriti" (Informan 4) dan "faktor keluarga amal gaya hidup mewah menyekat amalan sikap berintegriti dalam alam kerjaya kepolisan" (Informan 7).

Rumusan dapatan menunjukkan faktor modul latihan, persekitaran tempat kerja dan faktor keluarga mempengaruhi pegawai polis untuk berintegriti atau sebaliknya. Sintesisnya, penemuan kajian mempunyai persamaan nilai dengan dimensi yang diketengahkan oleh Teori Integriti Organisasi Kepolisan dan Model Pemindahan Latihan Elangovan dan Karakowsky. Dimensi teknik kawalan pelanggaran integriti dalam Teori Integriti Organisasi Kepolisan meletakkan latihan sebagai medium kawalan pelanggaran integriti mempunyai persamaan dengan dapatan kajian tentang impak latihan terhadap pengetahuan, kemahiran dan sikap berintegriti pegawai polis. Dimensi peraturan organisasi juga mempunyai persamaan nilai dengan dapatan kajian. Ia merupakan antara impak modul latihan integriti yang menjadi amalan dan mekanisme kawalan pelanggaran di tempat kerja sebagaimana syor dikemukakan teori ini. Selain itu, penemuan kajian berhubung faktor persekitaran tempat kerja mempunyai persamaan dengan elemen yang diketengahkan dalam Model Pemindahan Latihan Elangovan dan Karakowsky. Model tersebut memperjelaskan bahawa persekitaran tempat kerja mempunyai pengaruh terhadap pengadaptasian pengetahuan, kemahiran dan sikap dari program latihan ke tempat kerja dan penemuan kajian turut menunjukkan penjelasan sama.

Penemuan baharu berhubung faktor keluarga mempengaruhi keberkesanan latihan dan pengamalan integriti dalam kalangan pegawai polis mempunyai persamaan nilai dengan dimensi pengaruh persekitaran sosio politik dalam teori ini. Keluarga sebagai komponen sosial terpengaruh dengan persekitaran masyarakat tidak berintegriti memberi impak negatif terhadap amalan integriti pegawai polis. Secara keseluruhan rumusan penemuan kajian seperti dalam Rajah 9. 


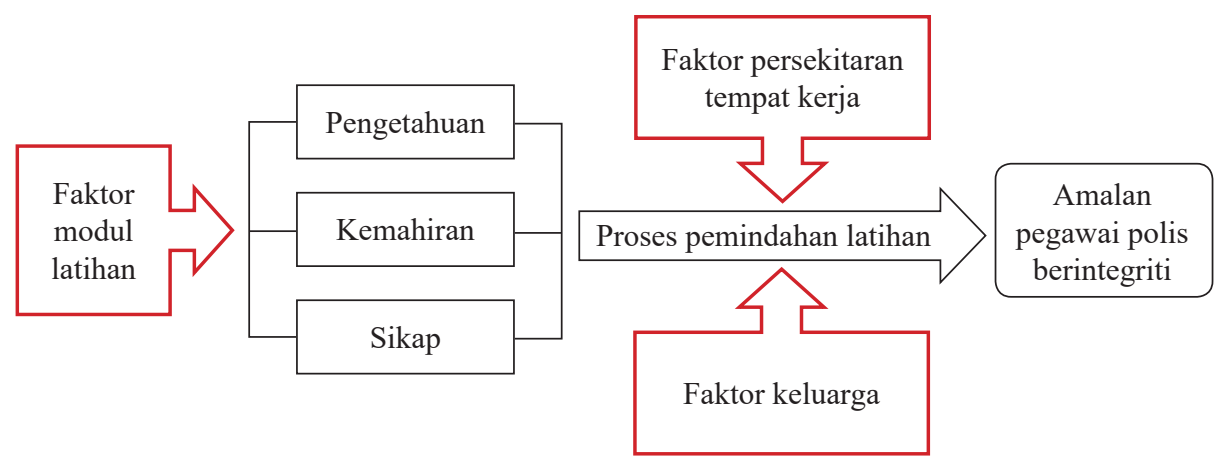

Rajah 9: Keberkesanan latihan terhadap amalan pegawai polis berintegriti.

Rumusannya, Teori Integriti Organisasi Kepolisan sangat releven bagi memperjelaskan amalan integriti dalam organisasi kepolisan. Perincian dimensi jelas menepati pemilikan ciri dan amalan organisasi kepolisan pelbagai negara. Demikian juga perincian Model Pemindahan Latihan Elangovan dan Karakowsky yang sangat relevan dengan proses pemindahan pengetahuan, kemahiran dan sikap dari program latihan kepada realiti persekitaran kerja sebenar. Namun, penemuan baharu kajian ini boleh memperkukuhkan lagi konsep model berkenaan.

\section{KESIMPULAN}

Kajian ini memberi sumbangan besar dan bermakna kepada perkembangan ilmu pengetahuan dalam konteks latihan dan integriti membabitkan organisasi kepolisan kerana kajian seumpama ini kurang dijalankan. Kajian ini menepati situasi semasa PDRM yang berhadapan pelbagai persepsi negatif masyarakat membabitkan integriti PDRM. Kajian keberkesanan PLAK terhadap amalan integriti pegawai polis memperjelaskan pengaruh faktor modul latihan integriti, persekitaran tempat kerja dan keluarga terhadap pemilikan dan pengamalan integriti pegawai polis. Modul latihan integriti dalam PLAK merupakan pencetus utama pemilikan integriti pegawai polis, namun peningkatan pengetahuan, kemahiran dan sikap berintegriti dari PLAK tidak menjamin pengamalannya dalam pelaksanaan penugasan. Faktor persekitaran tempat kerja dan faktor keluarga mempengaruhi amalan integriti secara konsisten. Disarankan kajian lanjutan mengkaji konteks pengamalan integriti secara mendalam bagi memahami situasi sebenar amalan integriti dalam organisasi kepolisan. 


\section{PENGHARGAAN}

Setinggi-tinggi penghargaan kepada pihak Jabatan Perkhidmatan Awam di atas penajaan pembiayaan pengajian doktor falsafah yang diberikan menerusi biasiswa Hadiah Latihan Persekutuan. Penghargaan juga kepada Universiti Kebangsaan Malaysia bagi Dana Cabaran Perdana DCP-2017-012/3 dalam menjayakan penulisan ini.

\section{RUJUKAN}

Abdul Rahim Bakar and Shamsiah Mohamed. 2008. Teaching using information and communication technology: Do trainee teachers have the confidence? International Journal of Education and Development Using Information and Communication Technology 4(1): 5-12.

Abdul Rahman Embong. 2017. Melangkaui 2020 ke arah 2050: Menangani cabaran baharu integriti negara. Siri syarahan perdana integriti Tun Abdullah Ahmad Badawi. Kuala Lumpur: Institut Integriti Malaysia.

Akauntan Negara Malaysia. 2019. Pengurusan integriti dan tatakelakuan penjawat awam. https://km.anm.gov.my (accessed 29 March 2020).

Akta Polis. 1967. Undang-undang Malaysia: Akta 344 Akta Polis 1967 sebagaimana pada 1 Oktober 2012. P.U. 385 A/1967. Kuala Lumpur: International Law Book Services.

Akta Suruhanjaya Integriti Agensi Penguatkuasaan. 2009. Undang-undang Malaysia: Akta 700 Akta Suruhanjaya Integriti Agensi Penguatkuasaan. Kuala Lumpur: International Law Book Services.

Ali Nufael. 2019. Isu integriti: Kemasukan baharu PDRM wajib lulus ujian agama, moral. BenarNews. 11 December. http://www.benarnews.org/malay/berita/police-test -12112019133231.html (accessed 11 December 2019).

Anis Yusal Yusoff and Mohd Nizam Mohd Ali, ed. 2016. A national integrity system. Kuala Lumpur: Institut Integriti Malaysia.

Azlah Md. Ali, Thuaibah, Rozeyta Omar, Noor Ella Mohamad Zip, Nor Suziani Ismail and Thahiroh Zulkifli. 2009. Keberkesanan latihan di kalangan kakitangan kumpulan sokongan di Pejabat Setiausaha Kerajaan Negeri Kedah Darul Aman. In Amalan latihan dan pembangunan sumber manusia di Malaysia, eds. Aminah Ahmad Khalid, Rozeyta Omar, Hashim Fauzy Yaacob, Hamidah Ab. Rahman, Azizah Rajab, Sheau Pey Kong, Azlah Md. Ali et al., 57-82. Skudai: Penerbit Universiti Teknologi Malaysia.

Azman Ismail, Noor Azmi Mohd Zainol and Nursaadatun Nisak Ahmad. 2016. Program pembangunan kepimpinan meningkatkan pemindahan latihan dalam Tentera Darat Malaysia: Kajian empirikal. Jurnal Pengurusan 46(2016): 149-161.

Balkisnah Shaharuddin and Norhasni Zainal Abiddin. 2009. Tinjauan faktor-faktor pendorong dan penghalang pemindahan latihan: Konteks Malaysia. Sosio Humanika 2(1): 107-123. 
Blumberg, D.M., L. Giromini and L.B. Jacobson. 2015. Impact of police academy training on recruits' integrity. Police Quarterly Sage Journals 19(1): 63-86. https://doi.org/10.1177/1098611115608322

Bulgarelli, A. and E. Gori. 2004. Information systems for the evaluation of the effectiveness and efficiency of vocational training programmes. Journal of Evaluation 10(2): 217-235. https://doi.org/10.1177/1356389004046293

Compton, M.T., R. Bakeman, B. Broussard, D. Hankerson-Dyson, L. Husbands, S. Krishan, T. Steward-Hutto et al. 2014a. The police based crisis intervention team (CIT) model: I. Effects on officers' knowledge, attitudes, and skills. Psychiatric Services 65(4): 517-522. https://doi.org/10.1176/appi.ps.201300107

2014b. The police based crisis intervention team (CIT) model: II. Effect on level of force and resolutions referral and arrest. Psychiatric Services 65(4): 523-529. https://doi.org/10.1176/appi.ps.201300108

Creswell, J.W. 2003. Research design: Qualitative, quantitative and mixed method approaches. 2nd ed. Thousand Oak: Sage Publication.

Dyrmishi A., D. Elona, V. Gjergji and S. Hroni. 2014. Police integrity and corruption in Albania. Albania: Institute for Democracy and Mediation.

Easdown, G. 1994. Student teachers, mentors and information technology. Journal of Information Technology for Teacher Education 3(1): 63-78. https://doi.org/ 10.1080/0962029940030106

Elangovan, A.R. and L. Karakowsky. 1999. The roll of trainee and environmental factors in transfer of training: An exploratory framework. Leadership and Organization Development Journal 20(5): 268-276. https://doi.org/10.1108/ 01437739910287180.

Fusch, P. I. and L.R. Ness. 2015. Are we there yet? Data saturation in qualitative research. The Qualitative Report 20(9): 1408-1416. https://doi.org/10.46743/2160-3715/ 2015.2281

Gotsch, A.R., C.W. Keck and H.C. Spencer. 2012. Knowledge, skills, and attitudes for the public health preparedness and response core competency model. Washington, DC: Centers for Disease Control and Prevention.

Haniza Hanim Mustaffa Bakri, Jamaliah Said and Zulyanti Abd Karim. 2015. Case study on integrity among Royal Malaysia Police: An ethical perspective. Procedia Economics and Finance 28: 121-125. https://doi.org/10.1016/S2212 -5671(15)01090-4.

Huberts, L.W.J.C., D. Pijl and A. Steen. 1999. Integriteit en corruptie. In Politie: Studies over haar werking en organisatie, eds. C.J.C.F. Fijnaut, E.R. Muller and U. Rosenthal. Alphen Aan Den Rijn: Samsom.

Institut Integriti Malaysia. 2004. Pelan integriti nasional. Putrajaya: Institut Integriti Malaysia.

InSites. 2007. Tips for analysing qualitative data. http://www.insites.org/CLIP_v1_site/ downloads/PDFs//TipsAnalzQualData.5D.8-07.pdf (accessed 5 April 2018).

Jabatan Integriti dan Pematuhan Standard. 2017. Sistem kawalan dadah dan disiplin. Arahan pentadbiran jabatan integriti dan pematuhan standard bil. 8/2019. 2019. Statistik JIPS. Bukit Aman: Polis Diraja Malaysia. 
Jabatan Pengurusan PDRM. 2006. Garis panduan pematuhan pelaksanaan program latihan asas kepolisan. Bukit Aman: Polis Diraja Malaysia.

Jamaliah Said, Mad Mahmudul Alam and Maizatul Akmar Khalid. 2015. Relationship between good governance and integrity system: Emperical study on the public sector of Malaysia. Humanomics 32(2): 151-171. https://doi.org/10 $.1108 / \mathrm{H}-02-2016-0008$

Kamaruzzaman Abdul Manan, Shuhaida Md Nor and Bahiyah Omar. 2013. Model penilaian Kirkpatrick: Mengkaji pengaruh komunikasi terhadap keberkesanan latihan. Jurnal Komunikasi 29(2): 31-50.

Klockars, C.B. and I.S. Kutnjak. 1999. The measuring of police delinquency. In The criminology of criminal law. Advances in criminological theory, Vol. 8, eds. W. Laufer and F. Adler, 87-106. New Brunswick: Transaction Publishers.

Klockars C.B., I.S. Kutnjak, W.E. Harver and M.R. Haberfeld. 2000. The measurement of police integrity. Research in brief, U.S. Department of Justice, Office of Justice Programs, National Institute of Justice, Washington, DC: Goverment Printing Office.

Kutnjak I.S. 2015a. Police integrity in Croatia. In Measuring police integrity across the world: Studies from establish democracies and countries in transition, eds. I.S. Kutnjak and M.R. Haberfeld, 97-123. New York: Springer. 2015b. Studying police integrity. In Measuring police integrity across the world: Studies from establish democracies and countries in transition, eds. I.S. Kutnjak and M.R. Haberfeld, 1-36. New York: Springer. http://doi.org/ 10.1007/978-1-4939-2279-6-1

Kutnjak, I.S and M.R. Haberfeld. 2015. Measuring police integrity across the world: Studies from establish democracies and countries in transition. New York: Springer. https://doi.org/10.1007/978-1-4939-2279-6-12

Kutnjak, I.S., M.R. Haberfeld and R. Peacock. 2015. Police integrity in the United States. In Measuring police integrity across the world: Studies from establish democracies and countries in transition, eds. I.S. Kutnjak and M.R. Haberfeld, 295-327. New York: Springer. https://doi.org/10.1007/978-1-4939-2279-6-11.

Lasthuizen, K.M. 2008. Leading to integrity: Emperical research into the affects of leadership on ethics and integrity. PhD diss., Vrije Universiteit Amsterdam.

Lobnikar, B. and G. Mesko. 2015. Police integrity in Slovenia. In Measuring police integrity across the world: Studies from establish democracies and countries in transition, eds. I.S. Kutnjak and M.R. Haberfeld, 153-181. New York: Springer. http://doi.org/10.1007/978-1-4939-2279-6-7.

Maizatul Haizan Mahbob. 2002. Konsep pengurusan Jepun: Implikasi ke atas kepuasan dan kecenderungan berhenti kerja di kalangan pekerja bawahan. Jurnal Komunikasi 18: 145-163.

MAMPU. 2012. Etos perkhidmatan awam. http://www.mampu.gov.my/3d-flip-book/ etos-perkhidmatan-awam (accessed 29 March 2020).

Maxwell, J.A. 2005. Qualitative research design: An interactive approach. California: Sage Publication. http://doi.org/10.1177/1094428106290193 
Megat Ayop Megat Arifin and Abdul Halim Ahmad. 2016a. Kepentingan budaya integriti dan etika kerja dalam organisasi di Malaysia: Satu tinjauan umum. Malaysian Journal of Society and Space 12(9): 138-149. 2016b. Konsep integriti dalam organisasi Polis Diraja Malaysia: Satu tinjauan awal. Malaysian Journal of Society and Space 12(8): 135-147.

. 2016c. Peranan whistleblowing dalam meningkatkan integriti anggota Polis Diraja Malaysia: Kajian ke atas kontinjen Perak. Journal of Social Sciences and Humanities 11(1): 137-160.

Mohamad Hafiz Rosli, Mohamad Azizal Abdul Aziz, Farahwahida Mohd and Jamaliah Said. 2015. Integrity system in Malaysian public sector: An empirical finding. Procedia Economics and Finance 28(2015): 260-265. http://doi.org/10.1016/ S2212-5671(15)01109-0

Mohammad Diah Hj Wahari and Harisham Ibrahim. 2016. Modul integriti agensi penguatkuasaan. Kuala Lumppur: Institut Integriti Malaysia.

Mohd Koharuddin Mohd Balwi, Rosman Md Yusoff, Mohd Azhar Abdul Hamid, Muhammad Fauzi Othman and Nasir Markom. 2012. Etika kerja dalam kalangan penjawat awam Malaysia: Perbincangan makro dan mikro ke atas pembuatan keputusan etika. Jurnal Teknologi 58(2012): 57-62.

Mollen Commission. 1994. New York City commission to investigate allegations of police corruption and the anticorruption procedures of the police department. New York: Commission Report.

Neuman, W.L. 2003. Social research methods, qualitative and quantitative approaches. 5th ed. Boston: Pearson Education.

Newstrom, J.W. 1986. Leveraging management development through the management of transfer. Journal of Management Development 5(5): 154-168.

Nik Hairi Omar, Azmi Awang and Azmi Abdul Manaf. 2012. Integriti dari perspektif pengaduan awam: Kajian kes di Jabatan Pengangkutan Jalan Malaysia. e-Bangi: Jurnal Sains Sosial dan Kemanusiaan 7(1): 141-145.

Nina Nurdiani. 2014. Teknik sampling snowball dalam penelitian lapangan. ComTech 5(2): 1110-1118. https://doi.org/10.21512/comtech.v5i2.2427

Peraturan-peraturan Lembaga Tatatertib Perkhidmatan Awam. 1993. (P.U. (A) 396/1993) dalam Perintah-perintah am dan arahan pentadbiran (hingga 1 Mac 2010). Petaling Jaya: International Law Book Services.

Polis Diraja Malaysia. 1993. Peraturan-peraturan pegawai awam (kelakuan dan tatatertib). P.U. (A) 395/1993. Arahan Ketua Polis Negara No. 133 (2018). . 2003. Perintah tetap Ketua Polis Negara: A302 bahagian latihan Polis Diraja Malaysia.

2010. Arahan pentadbiran bil. 21/2010: Ketua Polis Negara 4/21. http://esiar .rmp.org (accessed 5 June 2018).

2015. Arahan Ketua Polis Negara: Sistem Kawalan Dadah dan Disiplin (20152017). http://esiar.rmp.org (accessed 3 June 2018).

2016. Pelan integriti PDRM 2016-2020. Kuala Lumpur: Polis Diraja Malaysia. 2017. Perintah Tetap Ketua Polis Negara: A110 - Tatatertib. Arahan pentadbiran JIPS Bil. 1/2018. KPN (PR) 19/30. 
Porter, L.E., T. Prenzler and K. Hine. 2015. Police integrity in Australia. In Measuring police integrity across the world: Studies from establish democracies and countries in transition, eds. I.S. Kutnjak and M.R. Haberfeld, 67-96. New York: Springer.

Pusat Latihan Polis. 2017. Prospektus pusat latihan polis Kuala Lumpur 2017. Kuala Lumpur: Pusat Latihan Polis.

Robson, C. 2002. Real world research: A resource scientists and practitioner-researchers. 2nd ed. UK: Blackwell.

Rohana Othman, Normah Omar, Asri Azam, Shafik Ibrahim, Wan Ahmad Farouq, Najla Rustam and Nooraslinda Abdul Aris. 2014. Influence of job satisfaction and codes of ethics on integrity among police officers. Procedia - Social and Behavioral Sciences 145 (2014): 226-276. https://doi.org/10.1016/j.sbspro.2014.06.034

Ruer, D. and Hasbee Usop. 2016. Penyiasatan kertas konsep latihan, pengetahuan, kemahiran dan sikap bagi polis pegawai penyiasat di Ibu Pejabat Polis Daerah Sarawak. International Journal of Science Commerce and Humanities 4(2): 22-29.

Ruer, D. 2017. Pembentukan penyiasatan profesional Polis Diraja Malaysia dalam perkembangan teknologi dan globalisasi. Putrajaya: Institut Keselamatan Awam Malaysia.

Rusli Ahmad, Hasbee Usop, Azman Ismail, Sopian Bujang and Nur NahaAbu Mansor. 2014. Conducting research in social sciences and management studies: Practical and a step-by-step guide. Sarawak: RS Publishing House.

Serguei, C., I.S. Kutnjak, Qasin Haq and M.R. Haberfeld. 2015. Police integrity in Russia. In Measuring police integrity across the world: Studies from establish democracies and countries in transition, eds. I.S. Kutnjak and M.R. Haberfeld, 153-181. New York: Springer. http://doi.org/10.1007/978-1-4939-2279-6-6

Shahren, A.Z.A. 2013. How to do a content analysis: A step-by step guide. Unpublished manuscript.

Siti Uzairiah Mohd Tobi. 2017. Kajian kualitatif dan analisis temu bual. n.p.: Aras Publisher.

Six, F.E and A. Lawton. 2013. Towards a theory of integrity systems: A configurational approach. International Review of Administrative Sciences 79(4): 639-658. https://doi.org/10.1177/0020852313501124

Ssonko, K.W.S. 2010. Ethics, accountability, transparency, integrity and professionalism in the public service: The case of Uganda. Paper presented at Capacity Building Workshop for Public Sector Human Resource Managers in Africa, Republic of Benin. 12-16 April.

Tate, W. 1995. Developing managerial competence: A critical guide to methods and materials. England: Gower House.

Thomson, S.B. 2011. Qualitative research: Validity. Journal of Administration and Governance 6(1): 77-82.

Thorne, S., S.R. Kirkham and J. Mac Donald-Ernes. 1997. Interpretive description: A noncategorical qualitative alternative for developing nursing knowledge. Research in Nursing and Health 2: 77-169. 
Veerasamy, L. and S.S. Raja. 2014. Integriti dalam perkhidmatan awam pada era Tunku Abdul Rahman Putra Al-Haj, 1957-1970. Journal of Department of History 23(1): 147-173.

Wan Idros Wan Sulaiman. 2001. Pembangunan personelia dalam aspek latihan dan pembangunan: Antara realiti dan formaliti keberkesanan tugas. Jurnal Komunikasi 17: 81-118.

2007. Pembangunan sumber manusia: Satu analisis terhadap keefisienan program latihan dan pembangunan. In Pembangunan sumber manusia dalam era k-economy, eds. Rahmah Ismail, Nor Aini Hj. Idris and Razak Mohd, 210-230. Selangor: Penerbit Universiti Kebangsaan Malaysia. 